San Jose State University

SJSU ScholarWorks

Master's Theses

Master's Theses and Graduate Research

1991

\title{
The effect of feedback message characteristics and perceived relationship on responses to feedback
}

Gwen Naftaly Carscadden

San Jose State University

Follow this and additional works at: https://scholarworks.sjsu.edu/etd_theses

\section{Recommended Citation}

Carscadden, Gwen Naftaly, "The effect of feedback message characteristics and perceived relationship on responses to feedback" (1991). Master's Theses. 101.

DOI: https://doi.org/10.31979/etd.pswq-7k58

https://scholarworks.sjsu.edu/etd_theses/101

This Thesis is brought to you for free and open access by the Master's Theses and Graduate Research at SJSU ScholarWorks. It has been accepted for inclusion in Master's Theses by an authorized administrator of SJSU ScholarWorks. For more information, please contact scholarworks@sjsu.edu. 


\section{INFORMATION TO USERS}

This manuscript has been reproduced from the microfilm master. UMI films the text directly from the original or copy submitted. Thus, some thesis and dissertation copies are in typewriter face, while others may be from any type of computer printer.

The quality of this reproduction is dependent upon the quality of the copy submitted. Broken or indistinct print, colored or poor quality illustrations and photographs, print bleedthrough, substandard margins, and improper alignment can adversely affect reproduction.

In the unlikely event that the author did not send UMI a complete manuscript and there are missing pages, these will be noted. Also, if unauthorized copyright material had to be removed, a note will indicate the deletion.

Oversize materials (e.g., maps, drawings, charts) are reproduced by sectioning the original, beginning at the upper left-hand corner and continuing from left to right in equal sections with small overlaps. Each original is also photographed in one exposure and is included in reduced form at the back of the book.

Photographs included in the original manuscript have been reproduced xerographically in this copy. Higher quality $6 "$ " 9 9" black and white photographic prints are available for any photographs or illustrations appearing in this copy for an additional charge. Contact UMI directly to order.

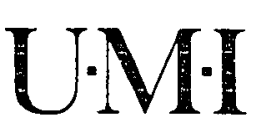

University Microfilms International

A Bell \& Howell Information Company

300 North Zeeb Road. Ann Arbor. Mi 48106-1346 USA

313/761-4700 800:521-0600 

Order Number 1944247

The effect of feedback message characteristics and perceived relationship on responses io feedback

Carscadden, Gwen Naftaly, M.A.

San Jose State University, 1991 
THE EFFECT OF FEEDBACK MESSAGE CHARACTERISTICS AND

PERCEIVED RELATIONSHIP ON RESPONSES TO FEEDBACK

A Thesis

Presented to

The Faculty of the Communication Studies Department San Jose State University

In Partial Fulfillment

of the Requirements for the Degree

Master of Arts

By

Gwen Naftaly Carscadden

May, 1991 
APPROVED FOR THE DEPARTMENT OF COMMUNICATION STUDIES

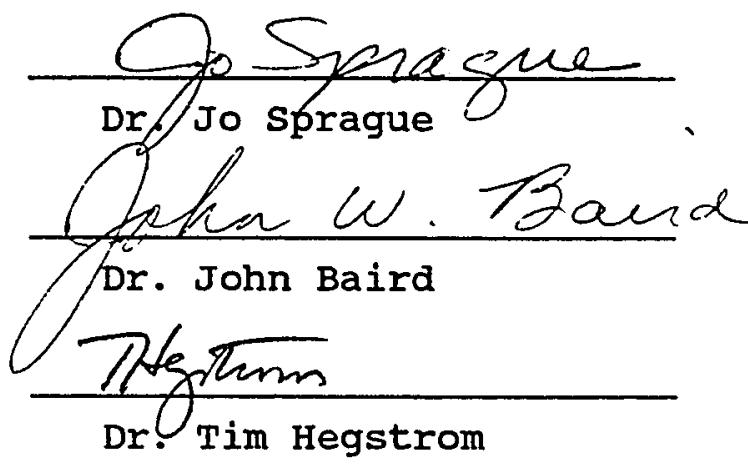

APPROVED FOR THE UNIVERSITY

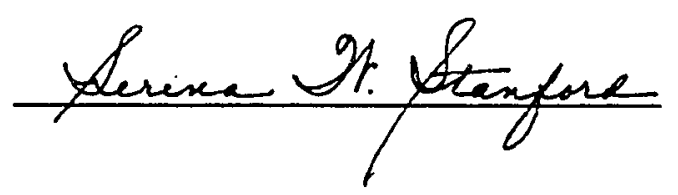


ABSTRACT

THE EFFECT OF FEEDBACK MESSAGE CHARACTERISTICS AND PERCEIVED RELATIONSHIP ON RESPONSES TO FEEDBACK

by Gwen Naftaly Carscadden

There is still little agreement as to the key factors that affect whether or not the recipient of a feedback message will change his/her behavior as a result of feedback .

This thesis examines the effect of feedback message characteristics and perceived relationship on responses to feedback. Respondents were given two questionnaires. The first one served to identify the perceived relationship variable, while the second one served to identify how the respondent would act after receiving either constructively or destructively phrased feedback (as defined in the study) from a specified feedback source. A Feedback Response Scale was developed in order to measure intent to change behavior.

The results of this study indicate that the way the feedback message was phrased (constructively or destructively) did have an effect on how the subject responded to the Feedback Response Scale, while the perceived relationship variable did not. 


\section{ACKNOWLEDGEMENTS}

There were many people who helped me to succeed with this project. I would like to acknowledge them and thank them for their contribution.

A special acknowledgement of gratitude is owed to my husband, Danny, who at the beginning of this project was my "special friend Danny." Without your supportive friendship, never ending patience, and special sense of humor, I'm sure I would have stumbled much, much more. This project would not have been possible if not for unconditional, undying support I have received from my parents who, among many other things, taught me that I could do or be anything I wanted to in life.

I would like to thank Dr. Tim Hegstrom and Dr. John Baird, members of my Thesis Committee, for all of their time, energy, and guidance. My special thanks to Dr. Jo Sprague, my Committee Chairperson, for all of the time spent in long meetings and on interstate telephone calls and for her special encouragement and positive attitude (especially during the times when I thought this process would never end).

Special thanks to Sean for understanding why I didn't have more time to play with you, and for all that 
you have taught me; to the rest of my family, phil, Kathy, and Roxanne, for their love and support; and to Rachel, who was supportive and encouraging from the very beginning and who has been an excellent role model as a manager and as a friend.

Grateful acknowledgement is made to my special friends Laura, Julie, and Chris for all of their support; to Eli for her wit, creativity, and encouragement on those days I wanted to give up; to my dear friend Toni who has always been there when I needed her to be; to Elayna for her support and creative ideas; to Eric I. (wherever you are) for your vast knowledge of statistics and for your willingness to help, and to Ann for her assistance in this process.

Finally, a very special acknowledgement of gratitude to PAM for watching over me, and for her endless bag of different colored M\&Ms. . the time has finally come! 
Page

ACKNOWLEDGEMENTS • • • • • • • • • • • • • • • • • iv LIST OF TABLES • • • • • • . . . . . • . . . . . viii Chapter

1. INTRODUCTION . . . . . . . . . . . . . 1 Review of the Literature . . . . . . . 3 Overview . . . . . . . . . . . . 3 Message Source . . . . . . . . . . 7 Message Characteristics . . . . . 10 Receiver Characteristics . . . . . . 14 Person Perception . . . . . . . . 15

2. METHOD . . . . . . . . . . . . 21 Subjects . . . . . . . . . . . 21 Design . . . . . . . . . . . . . 21 Hypothesis 1. . . . . . . . . . 22 Hypothesis 2. . . . . . . . . . 22 Hypothesis 3 . . . . . . . . . . 22 Operational Definitions . . . . . . . 23 Constructively Phrased Feedback . . . 23 Destructively Phrased Feedback . . . . 24 Perceived Relationship . . . . . . . . 25 Low Relationship . . . . . . . . . 25 High Relationship . . . . . . . . 25 
TABLE OF CONTENTS (Continued)

Chapter

Page

Development of Research Instrumentation . . 26

Development of Scales . . . . . . 26

Procedure . . . . . . . . . . . 30

Data Analysis . . . . . . . . . . 33

3. RESULTS . . . . . . . . . . . . . 34

Reliability Test Findings . . . . . . 34

Primary Findings . . . . . . . . 37

4. CONCLUSION . . . . . . . . . . . . . 41

Summary . . . . . . . . . . . . 41

Discussion . . . . . . . . . . 42

Limitations . . . . . . . . . . . . 44

Recommendations . . . . . . . . . 46

REFERENCE LIST . . . . . . . . . . . . . . . 50

APPENDICES . . . . . . . . . . . . . . . . . 55

A. SELF-PERCEPTION QUESTIONNAIRE . . . . . . . 56

B. PERCEIVED RELATIONSHIP QUESTIONNAIRE,

PHASE I . . . . . . . . . . . . . . . 59

C. FEEDBACK MESSAGE INDICATOR . . . . . . . 68

D. PRELIMINARY FRS QUESTIONNAIRE: CONSTRUC-

TIVELY PHRASED . • . . . . . . . . . . 71

E. PRELIMINARY FRS QUESTIONNAIRE: DESTRUC-

TIVELY PHRASED • . • . . . . . . . . . . 74

F. PERCEIVED RELATIONSHIP QUESTIONNAIRE,

PHASE II 


\section{LIST OF TABLES}

Table

Page

1. Correlation Coefficients for Items on the

Feedback Response Scale . . . . . . 35

2. Ranges in Scores for Perceived Relationships 36

3. Multivariate Analysis of Variance Summary for Message and Relationship Variables . . . 38

4. Mean Responses to Feedback Response Scale . . 39 
Chapter 1

INIRODUCTION

In today's society interpersonal communication skills are essential. Whether one is speaking with a friend, colleague, or family member, the proper communication "tools" are necessary in order to send and receive clear and meaningful messages. One such "tool" is described by the term "feedback."

Although the topic of feedback has been studied from many angles, and it is agreed that the topic is certainly worthy of study, there is still little agreement as to the key factors that affect whether or not the recipient of a feedback message will change his/her behavior as a result of feedback. In a review of the evidence relating to feedback in the work setting, Herold and Greller (1977) concluded that although the concept of feedback was deemed central to issues such as performance, motivation, satisfaction, and training, little empirical effort has been expended in an attempt to understand it, and especially to understand its effects. To date, with the exception of a few investigations (see Ilgen, Fisher, \& Taylor, 1979), most studies examining the feedback process and its effectiveness focus on one of the two main 
components of the process, eithex the sender characteristics or the message characteristics. Within each area, there are sets of studies which manipulate specific components. For example, within the body of literature on sender characteristics, one of the most commonly manipulated variables is sender (source) credibility. Studies in this area tend to examine and attempt to predict whether receivers will act on the feedback they receive based on how credible they perceive the sender to be. The literature on message characteristics, on the other hand, examines the actual message in an effort to determine whether or not the receiver will change his/her behavior based on the way the message is stated. These studies include the manipulation of such factors as timing and valence of feedback messages.

Therefore, taking into account the above overview and some of the areas that have been explored, it appears that up to this point, the study of the feedback process has been limited to manipulation of specific components such as message and source. The present study, however, examines the feedback process in a somewhat different light. This study is an examination of the effect that a receiver's perceptions has upon the way he/she will respond to feedback messages. By incorporating concepts from the self-concept and meta-perspectives areas of 
research (see Laing, Philipson, \& Lee, 1966; Scheff, 1967), as well as research from various other fields of study, this study examines the differences in the way people respond to feedback based upon how the message is phrased, and based upon the relationship the receiver perceives he/she has with the sender of the feedback message.

Review of the Literature

\section{Overview}

Research in the area of feedback is extremely varied. The concept of feedback has been researched and written about by authors from several disciplines including psychology, communication studies, and business administration. While studies from each discipline will be highlighted, the main focus of the following review of the literature will be on literature from the communication studies and business administration areas as they pertain to feedback within the organization.

There are various definitions of feedback. Annett (1969) defines feedback as "information received by an individual about his or her past behavior." Bourne (1963) supplements this definition by asserting that feedback provides some information about the "correctness, accuracy or adequacy of the response or behavior." 
Ilgen et al. (1979), in what is considered to be perhaps the most comprehensive review of feedback research, define feedback as "a special case of the general communication process in which some sender (source) conveys a message to a recipient; in the case of feedback, the message comprises information about the recipient" (p. 350). While each discipline has specific methods of examining feedback, all seem to have difficulty defining exactly what comprises feedback. According to Duncan and Bruwelheide (1985), "Information feedback is a concept and a procedure which has occupied researchers and practitioners of Industrial/Organizational Psychology for the major portion of this century" (p. 91). The authors further state that the "growing amount of feedback literature has made many attempts to systematize and thus lend greater understanding to this cumbersome and disorganized aggregation of methods and procedures which we call feedback" (p. 91).

In addition, there are those researchers who believe the feedback process should be broken down and analyzed, while still others insist the process must be looked at as a whole. Ilgen et al. (1979), for example, argue that feedback should be studied as a complex process, rather than in individual components, as often happens. In an argument for researching feedback as a process that 
involves source, message, and recipient, the researchers assert that the perception and acceptance of feedback are important determinants of the responses and reactions to feedback. As Olgilvie and Haslett (1985) describe in their summary of the research in the area of feedback, "They (Ilgen et al.) identified four important processes in feedback. First, individuals must perceive the feedback. Second, they must accept it. Third, they must then develop the intentions to respond and finally they must set specific, moderately difficult goals for improvement" (p. 389). Ilgen et al. (1979) further state that most of the previous research falls into one of two categories: (1) studies that relate to a specific dimension of feedback (source or receiver) which often consist of rigorous experimental research on tasks that tend to be very abstract. This is especially apparent in research done in the field of psychology, where test subjects are often given feedback based on their performance on a particular task or set of tasks; (2) studies that discuss feedback in terms of motivational orientation, which then fail to examine the specific components of the feedback process. Larson, Glynn, Fleenor, and Scontrino (1986), in a critical analysis of current feedback research, assert that most of the current research on the topic of feedback focuses on certain specific dimensions. 


\begin{abstract}
- . empirical investigations examining performance in organizations have also begun to adopt a more multidimensional perspective. Most notably, instruments have been developed for use in natural field settings that assess several different dimensions of the performance feedback people receive . . . and studies employing these measures have started to investigate the relationship between the assessed feedback dimensions and such outcome variables as the recipient's acceptance of the feedback, motivation to perform well, and job satisfaction. (p. 1084)

The authors argue that, although studying individual
\end{abstract} components of the feedback process has been the most widely accepted method of study, perhaps "feedback dimensions actually covary so strongly as to be empirically indiscriminable, then not only may we be gaining nothing by treating them separately, we may actually be diminishing our understanding of naturally occurring feedback phenomena" (p. 1085) .

As stated previously, within the realm of literature pertaining to the study of feedback there are several main sub-areas of study: studies which focus on sender characteristics, such as credibility and trustworthiness, and studies which focus on the actual feedback message itself (generally focusing on whether the message is positive or negative). Research relating to these subareas will be discussed in the following sections. 
Message Source

A substantial amount of research has been dedicated to studying the source, or sender, of the feedback message. In a review of the literature on source characteristics, Cusella (1982) asserts that the source of the feedback "may be the most important influence on the receivers' acceptance of the feedback" (p. 18). Further, Ilgen et al. (1979) advanced that the source of a feedback message is an important dimension. In particular, they emphasize the importance of the "credibility" and the "power" of the source.

Credibility refers to the knowledge of the source concerning the performance of the individual, and his or her familiarity with the task per se. Power refers to the extent to which the source influences or has control over rewards and punishers related to the worker's performance. (Duncan \& Bruwelheide, 1985, p. 98)

Various studies have demonstrated that credibility of the source is an important dimension of feedback (Banister, 1986; Cusella, 1982; Griffin, 1967; Greller \& Herold, 1975b; Ilgen et al., 1979). Tuckman and oliver (as cited in Duncan \& Bruwelheide, 1985) found that "feedback from supervisors decreased classroom performance of a teacher, while student feedback improved (teacher) performance" (p. 103). The authors suggest this occurred because the students were considered by the teachers to be more 
credible sources, as they were in constant contact with the teachers. The supervisors, on the other hand, were removed from the situation and had little direct observational knowledge of the teachers' performance. Cusella (1982) conducted a study in which he investigated the effects of verbal feedback on the intrinsic motivation of task performers. Specifically, he examined the effects the expertise of the feedback source (high vs. low) and the valence of the message (positive vs. neutral) had on motivation to perform tasks. Subjects were given either positive or neutral feedback from a source who was introduced to them as either a faculty member, appearing very organized, or a junior in college, appearing to be very disorganized. Results indicated that the high expertise feedback source did enhance intrinsic motivation. The researcher suggests that feedback from highly credible sources is more readily accepted because it has a higher reward value and promotes feelings of self-worth. Further, in a study along the same lines as his study, the author points out that, Klein, Kraut, and Wolfson (1971) found that employees' satisfaction with the company feedback varied, depending on their perceptions of the feedback source's familiarity with the relevant job or work unit. Receivers were much less satisfied with feedback from individuals far removed from their work setting. (p. 19) 
While different researchers conceptualize credibility differently (Griffin, 1967, specified five distinct dimensions of source credibility, Ilgen et al., 1979, list two, etc.), most include the concepts of expertise and trustworthiness. As might be predicted, research indicates that feedback from sources perceived as being more credible is generally more effective (Ilgen et al., 1979; O'Reilly \& Anderson, 1980). It is important to note, however, that "effective" in terms of the above-mentioned studies refers to the accuracy of the feedback reception. In other words, feedback was seen as effective if subjects indicated that they understood what was being said to them.

Along the same lines, Olgilvie and laslett (1985) identify two other source characteristics that have been shown to affect feedback acceptance: (1) power and status of the sender, and (2) the communicator style of the sender. According to Olgilvie and Haslett (1985), a manager who has direct control over his/her subordinates will exert a powerful influence over those employees, and thus, "leaders are generally perceived as giving more accurate, credible feedback" (p. 391). The researchers also link source power to source expertise; they, too, maintain that the recipient of a feedback message is more 
likely to accept and act upon the information if it comes from a source the recipient believes to be competent. IIgen, Mitchel1, and Fredrickson (1981) conducted a study in the work setting in which they manipulated such things as the supervisor's power over subordinate pay and the exact nature of the feedback given to the subordinates. Their findings concur with those cited above in that they also found that subordinates were "influenced by the leader's power as it interacted with the nature of the feedback" (p. 386).

Finally, according to olgilvie and Haslett (1985), the communicato: style, or the manner in which the feedback is given, also plays an important part in how feedback is received. In a study where group members varied in the clarity, mood, dynamism, and criticalness of their feedback, the researchers report that the "effectiveness of feedback was significantly related to the source's verbally assertive style, dynamism, responsiveness and being relaxed" (p. 392).

\section{Message Characteristics}

The way in which a feedback message is presented is extremely important (Cusella, 1982; Ilgen et al., 1979; Hunsaker \& Alessandra, 1987; Beck \& Beck, 1986; Verderber, 1979; Kastelen, Nickel, \& McLaughlin, 1984). 
According to an article which appeared in the San Jose Mercury News, in a recent study of managers, researchers found that the "poor use of criticism was among the top five most often mentioned causes of conflict at work" (p. 1L). This finding concurs with previous research focusing on conflict within the workplace, specifically Gibb's (1961) delineation of supportive and defensive communication climates. The authox suggests that managers can create supportive or defensive communication climates based upon their choice of words to their employees. According to Gibb (1961), supportive climates are characterized by communication that displays such qualities as equality, description, spontaneity, problem orientation, provisionalism, and empathy, while defensive communication climates are characterized by communication that reflects superiority, evaluation, strategy, control, certainty, and neutrality.

Based on this review of the literature, it seems that the majority of the studies that manipulate message content focus on how what they term the "valence" of the feedback message (positive or negative) affects how the receiver will perceive the feedback. Almost without exception, the researchers found that positive feedback was more readily accepted than negative feedback. In addition, people tend to remember positive feedback more 
often than negative feedback (see Ilgen et al., 1979;

Cusella, 1982; Stone, 1985). According to Ilgen et al. (1979),

The most reasonable explanation for this (that positive feedback would be more readily accepted), relies upon a defense mechanism interpretation, in which positive feedback tends to enhance one's self-image. As a result, positive feedback tends to be perceived accurately. Negative feedback, on the other hand, may be denied by the recipient because of an unwillingness to accept such knowledge about him or herself. (p. 354)

From an organizational perspective, the majority of studies conducted approach the feedback process by examining supervisors' performance feedback to subordinates. While feedback is seen as a key factor for enhancing overall effectiveness in organizations, it has also been found that supervisors often avoid giving negative feedback to their subordinates (Larson, 1986).

In their review of literature pertaining to feedback research, Olgilvie and Haslett (1988) also list timing and the way in which the feedback is transmitted (the channel) as important message characteristics. According to the authors, current research in the field indicates that feedback should be given relatively close to the behaviors or jobs done. Delays may reduce the impact and relevance of the feedback. In terms of the most desirable channel, Furnham (1982) found that most people 
prefer to give feedback face-to-face, rathex than in writing or over the phone.

Also within the area of message content, there is a large body of prescriptive literature. Most of this includes short "how to" articles that give step by step advice on how one should go about giving feedback, or criticism, as it is often referred to in these articles. Generally, a few overall rules are stated (e.g., be specific, use "I" messages, and use non-threatening language) and then examples are given (see Beck \& Beck, 1986; Bennett \& Olney, 1986; Cliff, 1987; Conti\& Fellenz, 1985; Dowst, 1985; Feinberg, 1986; Hunsaker \& Alessandra, 1987). Johnson (1979), for example, asserts that in order for feedback to be the most effective, or constructive, it must be specific (focusing on observations rather than inferences), nonevaluative (focusing on descriptions, rather than judgment), and non-threatening (focusing on the behavior, not the person him or herself). Nelton (1985), in a similar vein, lists the following guidelines for giving effective feedback:

1. Keep in mind that feedback should be helpful to the person receiving it.

2. Be specific and accurate.

3. Feedback should be given in a way that communicates acceptance of the recipient as a worthwhile person. 
Verderber (1979), in much the same prescriptive fashion, cautions the reader that, "As with any other skill we have discussed, there are right ways and wrong ways as well as right times and wrong times for giving feedback" (p. 57). The author goes on to list what he has determined to be the most effective ways to give feedback. While there are numerous studies examining reactions to feedback based upon whether or not the overall message is positive or negative, it appears that the actual content of feedback messages has yet to be systematically studied. There is a substantial amount of research that offers prescriptive advice about how or when to give feedback. These articles, however, do not seem to be based on actual empirical data. The present study utilizes a more empirical approach and examined how varying the message phrasing can affect recipients' responses to feedback.

Receiver Characteristics

Within the feedback research, there are also some studies which indicate that the response to a feedback message has to do with the characteristics of the recipient of the message. Although research in this area is scant, Ilgen et al. (1979) list two recipient characteristics that have been shown to affect response to 
feedback: the recipient's mind set and the recipient's personal qualities. Mind set refers to the recipient's frame of reference at the time the feedback is given. For example, if an employee has just had an argument with a co-worker, he/she would probably not respond very favorably to that same co-worker's feedback about his/her performance.

Personal qualities refers to such characteristics as self-esteem and social anxiety. It has been demonstrated that people respond differently to feedback based on their level of self-esteem (Ilgen et al., 1979).

\section{Person Perception}

Yet another area of communication research pertinent to this study is research having to do with interpersonal perception, that is, research that studies the values and intentions that one believes another to possess either about themselves or others (Grunig, Stamm, \& Tichenor, 1973). According to Laing, Philipson, and Lee (1966), every person has a direct perspective and a metaperspective. As Laing et al. state,

My view of the others' view of me, my perspective on the others' perspective on me is what we are calling a meta-perspective and the other that $I$ take myself to be for the other, how I think you see me, is what we are calling meta-identity.

In an article that serves as an introduction to studies having to do with interpersonal perception, the authors 
state that, "the core model guiding all these studies is that of interpersonal perception--i.e., social events that grow out of the values and intentions that one person believes another to possess" (p. 465). The authors further assert that articles about person perception are an "ancient tradition" in social psychology literature.

In an article discussing interpersonal approaches to communication research, McLeod and Chaffee (1973) point out the following:

The key assumption underlying this type of research (research having to do with person perception) is that a person's behavior is not based simply upon his private cognitive construction of his world; it is also a function of his perceptions of the orientations held by others around him and of his orientation to them. (p. 471)

Perhaps even more importantly, the authors also state that under certain conditions of interaction, "the actual cognitions and perceptions of others will also affect behavior" (p. 471).

Within the context of organizational research, Infante and Gordon (1979) state that, "interpersonal perception and communication are the foundation of subordinate-supervisor relationships. . ." (p. 212). In their examination of subordinate and superior perceptions, they found that perceptions of self, of the other, and 
beliefs about how one is perceived by the other appeared to be the most important determinants in the communication relationship (p. 212).

Bacon (1986) emphasizes the importance of person perception in an attempt to develop a coorientation model and measure of organizational communication. While Bacon's research focuses mainly on perceptions of others' perceptions in relation to some thing rather than some other person, she does suggest that the issue of person perception as a whole is an integral part of the superior subordinate communication relationship. According to Bacon, "there is little knowledge regarding the extent of the difference in perceptions supervisors and subordinates may have of fundamental organizational issues, and the implications those differences may have for communication" (p. 2) .

In summary, it has been shown that the nature of feedback has been a topic of controversy for some time. Many researchers have offered definitions of feedback (see Ilgen et al., 1979), and many attempts have been made to operationalize the construct; entire articles have been devoted to discussing whether or not the construct should be researched as a complicated process (see Ilgen et al., 1979) or broken down into individual components (see Cusella, 1982; Larson, 1986). While most researchers 
agree that the feedback process is complex, there is still disagreement about the most productive way to study feedback and its effects.

While researchers have examined message source in terms of such variables as credibility and trustworthiness (Cusella, 1982; Ilgen et al., 1979; O'Reilly \& Anderson, 1980), and message content in terms of such variables as valence and timing, this review has not revealed any research that examines source or message characteristics as they relate to the receiver's perceptions of the relationship with the sender. Since it is well established that the recipient's opinion of the person sending the message influences how he or she will respond, it is reasonable to suggest that the recipient's perception of the sender's relationship to him/her may also be an important factor in how one responds to feedback.

Further, although there has been much research conducted within the area of feedback, each study seems to measure the effects of feedback in a different way. Some researchers (particularly in the field of psychology) measure the effects of feedback by change in behavior pertaining to specified tasks. Other researchers (particularly those in the area of organizational communication) measure feedback message effect by such 
indicators as satisfaction with supervisor or satisfaction with job.

In a call for a more systems-like approach to

examining feedback and its effectiveness, Duncan and Bruwelheide (1985) argue for more research that focuses on whether or not recipients of feedback will actually change their behavior as a result of feedback given to them. The authors state that:

rather than simply pointing out that "feedback" was used the researcher should discuss the behavioral mechanism most likely to affect performance. The researcher should then discuss how the design of feedback in that study uniquely provides for that behavioral mechanism to operate. Such a practice would require the researcher and eventually the practitioner to think in terms of behavior processes rather than mere handy techniques, and might foster the design of feedback forms best suited to behavior functions in field settings. ( $p$. 93)

The present stuảy is an attempt to determine if feedback message construction and/or perceived relationship has an effect on how an individual will respond to feedback. In an effort to better measure the effects of different feedback messages, a Feedback Response Scale was developed. While this study does not examine actual behavior change, this scale attempts to measure what changes subjects themselves predict they will make in their behavior. 
Specifically, in light of the obvious lack of research in the area of feedback messages as they relate to person perception, and as a first step toward providing some understanding of the process of responding to feedback, three hypotheses are proposed:

1. The way a feedback message is phrased (constructively vs. destructively) will have an effect on how one responds to a feedback message. An individual's responses will be higher on the Feedback Response Scale (FRS) when he/she receives a constructively phrased message.

2. Perceived relationship will have an effect upon how an individual responds to a feedback message. An individual's responses will be higher on the Feedback Response Scale (FRS) when he/she receives a message from a high relationship person.

3. The way a feedback message is phrased will interact with the perceived relationship to affect how individuals respond to a feedback message. 


\title{
Chapter 2
}

\author{
METHOD
}

Subjects

Subjects were 40 respondents who were solicited through acquaintance networks. At least 30 of the subjects were communication studies students at local colleges. All subjects were employed.

\section{$\underline{\text { Design }}$}

The goal of this study was to determine if there is a difference in the way people respond to constructively and destructively phrased feedback messages (as measured by the Feedback Response Scale), and if there is a difference in the way people respond to feedback based upon the relationship the respondent perceives he/she has with the sender of the message.

The two independent variables in this study were the feedback message and the perceived relationship, as determined by the receiver of the feedback. The dependent variable was the way feedback was received, as measured by the Feedback Response Scale (FRS).

As stated in the previous chapter, the following hypotheses were examined: 


\section{Hypothesis 1}

The way a feedback message is phrased (constructively vs. destructively) will have an effect on how one responds to feedback. Respondents' mean responses will be higher on the Feedback Response scale when they receive a constructively phrased feedback message.

\section{Hypothesis 2}

The valence of the perceived relationship will have an effect on how one responds to a feedback message. Respondents' mean responses will be higher on the Feedback Response scale when they receive a message from a high relationship person.

\section{Hypothesis 3}

The way a feedback message is phrased will interact with the valence of the perceived relationship to affect responses to a feedback message.

Utilizing a $2 \times 2$ repeated measures design, the following four conditions were compared:

$$
\begin{aligned}
1= & \text { High relationship/Constructively phrased } \\
& \text { feedback } \\
2= & \text { High relationship/Destructively phrased } \\
& \text { feedback } \\
3= & \text { Low relationship/Constructively phrased } \\
& \text { feedback }
\end{aligned}
$$




$$
4=\begin{aligned}
& \text { Low relationship/Destructively phrased } \\
& \text { feedback }
\end{aligned}
$$

Mean scores were tabulated for each of the four conditions. The alpha level for statistical significance was set at .05 .

\section{Operational Definitions}

For purposes of this study, feedback is defined as "information received by an individual about his or her past behavior" (Annett, 1969). Additionally, each of the feedback messages utilized in the study can be considered to be negative feedback in that they criticize the receiver's behavior in some way. The key difference, however, is in the actual phrasing of the feedback-whether it is phrased constructively or destructively.

\section{Constructively Phrased Feedback}

Utilizing communications studies literature as a guide to what to do when giving feedback, six feedback messages were created. The four messages that scored the highest when tested were determined to be the best examples of how to phrase feedback and were therefore utilized. For purposes of this study, the following four Feedback messages were termed Constructively Phrased Feedback: 
1. I don't often hear you introduce new ideas about how you can increase productivity within your work area; without your input, I feel like the whole burden falls on me.

2. You've been 10 to 15 minutes late for our last several meetings. When I have to sit and wait, I get angry and that gets in the way when we do start the meeting.

3. Mary just told me that you told her we were getting a new vice president. This concerns me because when I told you this news, I asked that you not mention it to anyone else.

4. You lost that report we need for the meeting and I had to spend my lunch hour making a new copy. Needless to say, I'm pretty upset.

Destructively Phrased Feedback

Utilizing some communication studies literature as reference, six negative feedback messages were constructed. The four messages that scored the lowest when tested were determined to be the most negative, and therefore they were used in the study. For purposes of this study, the following four feedback messages were termed Destructively Phrased Feedback:

1. You never make any suggestions or bring up any new ideas at our monthly staff meetings; can't you think of any?

2. You can't be trusted with any confidential information! I just found out that you blabbed the news about the new vice president. You should know that was supposed to be just between you and me.

3. No one can ever count on you. You're never where you say you are going to be. Is your time more valuable than ours? 


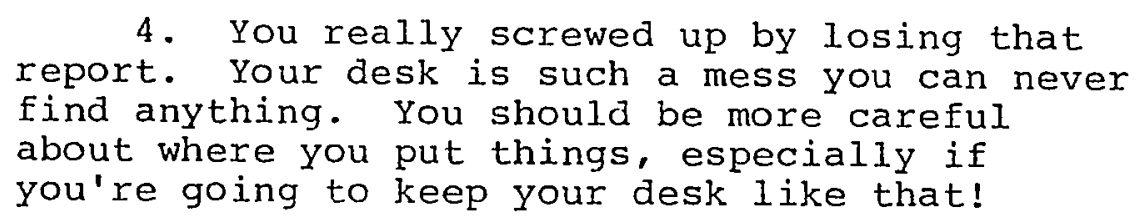

Perceived Relationship

For the purposes of this study, perceived relationship refers to the degree to which the respondent feels the person he/she is answering the survey about likes or dislikes him/her. Therefore, the second independent variable, source characteristics, or more specifically, in the case of this study, perceived source characteristics, is operationalized by the perception questionnaire (see Appendix B, Part D) .

Low Relationship

Low relationship refers to the person the respondent feels perceives him/her the most negatively. This was determined by totalling the scores for each of the five people about whom the respondent completes the perception questionnaire. The one having the lowest score was determined to be the person with whom the respondent has the lowest perceived relationship.

\section{High Relationship}

High relationship refers to the person the respondent feels perceives him/her the most positively. This was determined by totalling the scores for each of the five 
people about whom each respondent completed the perception survey. The one having the highest score was then referred to as the person with whom the respondent has the highest perceived relationship.

\section{Development of Research Instrumentation}

Development of Scales

Because of the lack of instrumentation available for a study of this specific nature, two instruments were developed, a Perceived Relationship Scale and a Feedback Response Scale, which will be described in the following sections.

Perceived Relationship Scale. In order to develop the Perceived Relationship Scale, 27 students from an undergraduate Interpersonal Communication Studies class were each given a list of 33 adjectives preceded by the statement, "If someone were to perceive me as (please fill in the word here) that person's overall evaluation of me would be - This was followed by a five-point semantic differential scale with "very positive" and "very negative" at either end of the scale (see Appendix A). The adjectives consisted of words that would be commonly used to describe character traits, such as "organized," "creative," and "cooperative." 
In determining which words or phrases to utilize, the researcher collaborated with several sources to come up with a list of words or phrases that would describe someone in terms of how they function in the work setting. Means for each word or phrase were calculated, and the seven words or phrases with the lowest means and the eight words or phrases with the highest means were determined. These 15 words were used in the final version of the scale. In the actual field condition, each respondent was given a packet of six of these scales. The respondent was asked to fill one out about him/herself, and to complete the remaining five as he/she believed that specified others would fill it out about him or her. The purpose of this scale was to determine the perceptions of the respondent in relation to others (see Appendix B). In addition, once means for each word or phrase were calculated, the four words with the greatest difference between their means were singled out to be described by feedback statements. (They were: innovative, dependable, one who can keep a secret, and organized.) Next, consistent with what prescriptive Iiterature in the area of feedback asserts are the correct and incorrect ways to give feedback (e.g., be specific, nonthreatening, use "I" messages), constructive and destructive feedback messages were written corresponding to each of the above mentioned 
adjectives. The feedback messages were then given to 30 Communication studies students who were considered "experts" in identifying constructive and destructive feedback, as they had just completed a unit on the subject and had tested satisfactorily on the material (see Appendix C). The four feedback statements determined to be the most constructive, and the four feedback statements determined to be the most destructive were selected to be used in the study.

\section{Feedback Response Scale (FRS). A Feedback Response} Scale was also developed in order to measure the effect of the individual feedback messages. There currently exists no single, agreed upon instrument that measures response to feedback. In fact, as mentioned in the previous chapter, one of the difficulties with current research in the area of feedback is the lack of consistency in terms of the operationalization of response to feedback. The Feedback Response Scale was developed with this in mind and may serve as a tool for future researchers to utilize. While we do not know exactly how one will respond if feedback is "effective," certain actions lead researchers to assume someone will change his/her behavior as a result of feedback (e.g., reporting that he/she found the feedback helpful, reporting that he/she was glad 
someone brought this to his/her attention, or reporting that he/she would continue a dialogue with the source of the feedback).

Three approaches were utilized in order to come up with the preliminary items for the scale: (1) current research in the field was examined, (2) students and faculty were informally surveyed as to how they would respond to constructively or destructively phrased feedback, and (3) the original 23-statement scale was reduced to 12 statements on the basis of a pretest in which 20 communication studies students (who had recently completed coursework involving the attributes of constructively phrased feedback) were each asked to complete the scale after reading either a destructively or constructively phrased feedback message (see Appendices $D$ and $E$ for examples). The scores of the 23 statements that followed the destructively phrased message were compared to the 23 that followed the constructively phrased message. If the scores differed by at least .6, it was determined that the particular item could be used to differentiate between constructively phrased and destructively phrased feedback; the item was then used in the final version of the Feedback Response Scale. The difference of .6 was used because it appeared to be a clear breaking point in the scores. When compared, most 
scores fell either well above or well below . 6 in difference.

To test for inter-item reliability, a Cronbach's alpha correlation analysis was conducted $(\alpha=.9125)$. All items correlated significantly with at least half of the other items, with most items correlating with all other items.

\section{Procedure}

Data were collected for this field study using a two-stage, self-report process. Respondents were first given Packet A (see Appendix B), which contained five identical Pexceived Relationship Scales. The first scale in the packet was a modified version of the Perceived Relationship scale. It consisted of the same list of 15 adjectives, each followed by a five-point semantic differential scale, ranging from "almost always" to "almost never." However, on this variation of the scale, the statement at the top of the page read as follows: "In general, I perceive myself as being . . (fill in the adjective here)." The purpose of inserting this preliminary version of the scale at the beginning of the packet was to collect any self-concept information that might be of use for later study. Also, a pilot study had revealed that respondents were confused about ratings of 
themselves without a prior opportunity to report to researchers their perceptions of how they "xeally were." Next the respondent was asked to list "ten people with whom you interact on a daily basis." This pool of 10 potential sources of feedback was then narrowed down to five names. For purposes of consistency, each respondent was asked to designate persons $2,4,6,8$, and 10 . After the five names were listed, the next set of instructions directed the respondent to complete five identical scales, similar to the one mentioned above (with the exception being the instructions at the top of the five scales read, "In general, the person listed above perceives me as being:." The "person above" was person $2,4,6,8$, or 10 (depending upon which of the five surveys the respondent is completing), thus providing the meta-perspective data. For example, if a subject's list contained the names Joe, Fred, Mary, Jane, Connie, Tom, Leslie, Dave, Rachel, and Patty, he/she would be asked to complete a survey as he/she perceived Fred would fill it out about him/her, the same survey as Jane would fill it out, and so on.

Totals from each of the five surveys were tabulated. The scale with the highest and the scale with the lowest total scores were identified. It was determined that the scale with the highest score identified the person the 
respondent perceived liked him/her the most (high relationship), and that the survey with the lowest score identified the person the respondent perceived liked $\mathrm{him} /$ her the least (low relationship). In the case of tie scores, the first scale in the series was used. Thus, two co-workers of each respondent (high relationship and low relationship, as defined above) were designated by name as feedback message sources and utilized in the next phase of the data collection.

Within a week, respondents received a second packet of surveys. This time the respondent was asked to respond to four separate feedback messages as if the person named had made the statement. Although respondents presumably thought the two names were selected at random, in fact the two message sources were the co-workers who, according to the scores on the previous set of surveys, the respondent perceived liked them the most or least. Each respondent was given two constructively phrased feedback messages, one attributed to the high relationship person and one attributed to the low relationship person, as well as two destructively phased feedback messages, also one attributed to the high relationship person and one attributed to the low relationship person. As indicated previously, eight feedback messages were created, covering four topics. While each respondent received two 
constructively phrased and two destructively phrased messages, the message topic, as well as the oxder in which the messages were presented, was varied. In each case, the respondent was asked to read the feedback statement, assume that it had been communicated to them by the co-worker named, and respond to the 12 items that followed each statement (the Feedback Response Scale; see Appendix $F$ for an example of the second packet).

\section{Data Analysis}

A total of 40 respondents completed both phases of the data collection; however, only 38 of the 40 survey sets collected were used in the data analysis, due to the fact that two of the packets contained incomplete information.

The data were subjected to a repeated measures ANOVA analysis to determine if differences existed between the groups (the actual statistical program utilized was sPSS MANOVA). The repeated measures design was appropriate in that each respondent was involved in all four experimental conditions. 
Chapter 3

RESULTS

As mentioned previously, 40 subjects, solicited through acquaintance networks, participated in this study. At least 30 of those who participated were communication studies students at local colleges. All of those who completed the study were employed. Thirty-eight of the surveys were utilized in the final analyses, as two of the surveys contained incomplete information.

Results of the analysis consisted of tests of the research hypotheses, as well as a reliability test that was conducted on the Feedback Response Scale.

\section{Reliability Test Findings}

As an added measure of reliability, items on the Feedback Response Scale were subjected to a Cronbach's Alpha analysis. Table 1 illustrates the results of the analysis. As the table indicates, the scale was shown to be reliable (alpha $=.91$ ).

Table 2 illustrates the ranges in the differences between the scores given to those the respondent felt liked him/her the most and those the respondent felt liked him/her the least (high relationship and low relationship). 


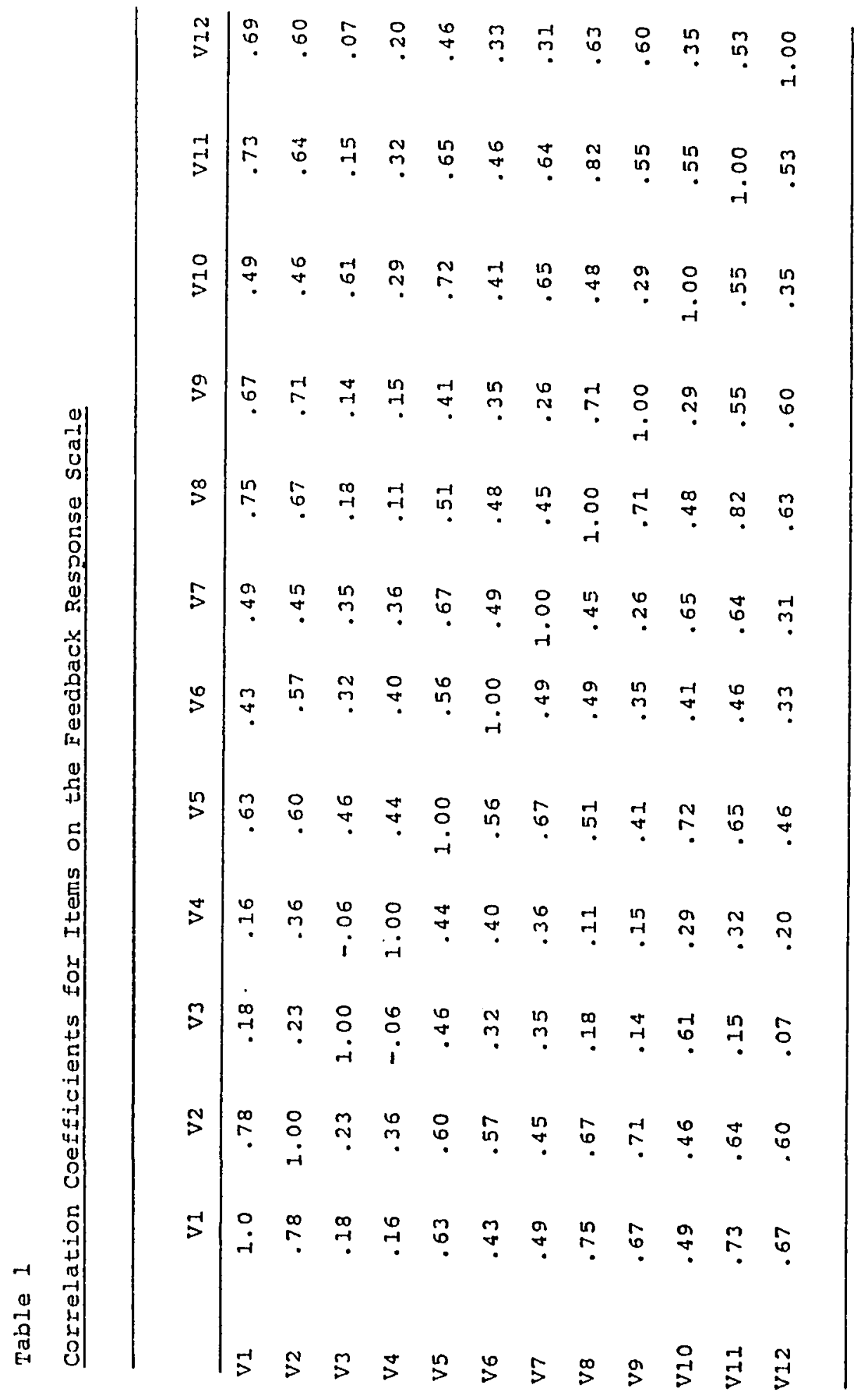


l'able 2

Ranges in scores for lerceived Relationships

\begin{tabular}{|c|c|c|c|}
\hline Subject & $\begin{array}{l}\text { Iligh Rel. } \\
\text { Coworker. }\end{array}$ & $\begin{array}{l}\text { Low Rel. } \\
\text { Coworker }\end{array}$ & Range \\
\hline 1 & 62 & 47 & 15 \\
\hline 2 & 69 & $\begin{array}{l}71 \\
55\end{array}$ & $\begin{array}{l}1.5 \\
14\end{array}$ \\
\hline 3 & 71 & 61 & 10 \\
\hline 4 & 68 & 59 & 9 \\
\hline 5 & 65 & 53 & 12 \\
\hline 6 & 75 & 71 & 4 \\
\hline 7 & 66 & 63 & 3 \\
\hline 8 & 72 & 67 & 5 \\
\hline 9 & 70 & 63 & 7 \\
\hline 10 & 72 & 67 & 5 \\
\hline 11 & 69 & 52 & 17 \\
\hline 12 & 61 & 50 & 11 \\
\hline 13 & 63 & 58 & 5 \\
\hline 14 & 69 & 62 & 7 \\
\hline 15 & 67 & 64 & 3 \\
\hline 16 & 75 & 69 & 6 \\
\hline 17 & 69 & 61 & 8 \\
\hline 18 & 72 & 61 & 11 \\
\hline 19 & 61 & 57 & 4 \\
\hline 20 & 71 & 55 & 16 \\
\hline 21 & 65 & 56 & 9 \\
\hline 22 & 74 & 55 & 19 \\
\hline 23 & 69 & 56 & 13 \\
\hline 24 & 75 & 58 & 17 \\
\hline 25 & 70 & 67 & 3 \\
\hline 26 & 58 & 45 & 13 \\
\hline 27 & 73 & 69 & 4 \\
\hline 28 & 65 & 52 & 13 \\
\hline 29 & 71 & 58 & 13 \\
\hline 30 & 71 & 54 & 17 \\
\hline 31 & 71 & 56 & 15 \\
\hline 32 & 67 & 60 & 7 \\
\hline 33 & 71 & 56 & 15 \\
\hline 34 & 71 & 57 & 16 \\
\hline 35 & 75 & 70 & 5 \\
\hline 36 & 69 & 55 & 14 \\
\hline 37 & 64 & 53 & 11 \\
\hline \multirow[t]{2}{*}{38} & 74 & 51 & 23 \\
\hline & & & \\
\hline
\end{tabular}

RANGE OF TIIE RANGES: 3 to 23

AVERAGE RANGE: $\quad 10.5$ 
The highest possible score, given the construction of the scale, was 75 , with the low being 15 (see Tables 1 and 2); therefore, the highest possible range between one respondent's high relationship and low relationship persons was 60 . As Table 2 indicates, the range of the ranges was from 3 to 23 , with the average being 10.5 .

Primary Findings

Hypothesis 1. The way a feedback message is phrased (constructively vs. destructively) will have an effect on how one responds to a feedback message. An individual's responses will be higher on the Feedback Response Scale (FRS) when he/she receives a constructively phrased message.

The results of the analysis clearly support Hypothesis 1. As Table 3 indicates, the way the feedback message was phrased significantly affected how the subjects responded to the items on the FRS. In addition, as Table 4 illustrates, mean responses to the items were substantially higher when the feedback message was constructively phrased, as were the mean responses for the scale as a whole. 
Table 3

Multivariate Analysis of Variance Summary for Message

and Relationship Variables

\begin{tabular}{lllllll}
\hline Demographic & Source & df & SS & MS & F & p \\
\hline
\end{tabular}

Message

Between Groups

Within Groups

$1 \quad 6711.18 \quad 6711.18$

$42.94<.0001$

$37 \quad 5782.32 \quad 156.28$

Relationship

Between Groups

$1 \quad 242.53$

$\begin{array}{lll}37 & 5884.97 & 159.05\end{array}$

$1.52 \quad .225$

within Groups

Interaction

Between Groups

Within Groups

$\begin{array}{lll}1 & 25.29 & 25.29\end{array}$

$.20 \quad .665$

$\begin{array}{lll}37 & 4603.21 & 124.41\end{array}$ 
Table 4

Mean Responses to Feedback Response Scale

\begin{tabular}{lccc}
\hline & Mean & Std. Dev. & N \\
\hline $\begin{array}{l}\text { Negative Message/ } \\
\text { Negative Relationship }\end{array}$ & 47.53 & 16.59 & 38 \\
$\begin{array}{l}\text { Negative Message/ } \\
\text { Positive Relationship }\end{array}$ & 49.24 & 15.56 & 38 \\
$\begin{array}{l}\text { Positive Message/ } \\
\text { Positive Relationship }\end{array}$ & 60.00 & & 38 \\
& & & \\
$\begin{array}{l}\text { Positive Message/ } \\
\text { Negative Relationship }\end{array}$ & 63.34 & 12.34 \\
\end{tabular}


Hypothesis 2. Perceived relationship will have an effect on how one responds to a feedback message. An individual's responses will be higher on the Feedback Response Scale (FRS) when he/she receives a message from a high relationship person.

The results of the data analysis did not support Hypothesis 2. As Tables 3 and 4 indicate, responses to items on the FRS scale were not significantly higher when subjects received a message from a high relationship person.

Hypothesis 3. The way a feedback message is phrased will interact with the perceived relationship to affect how individuals respond to a feedback message. No significant interaction effects were found $(\underline{p}<.05)$; therefore, Hypothesis 3 was not supported.

Table 3 illustrates the results of the analysis of variance for the message and relationship variables. Table 4 lists the mean responses for each of the four conditions. As the table indicates, the mean responses to the Feedback Response Scale ranged from 47.53 for the Negative Message/Negative Relationship condition to a high of 63.34 for the Positive Message/ivegative Relationship condition. 


\section{Chapter 4}

\section{CONCLUSION}

\section{Summary}

The review of the literature on feedback research led to three hypotheses which predicted differences in the way an individual would respond to feedback messages based upon either source or message characteristices, or both. Findings of message characteristic studies indicate that whether the message is negative or positive affects how an individual will respond to feedback. Studies manipulating source characteristics revealed that various source characteristics influence respondents of feedback messages; in particular, it was found that the more credible a source appears, the greater the effect of the message. Different dimensions of feedback were discussed with an emphasis on the fact that theorists not only disagree on how to study feedback, they also disagree on what dimensions actually comprise the feedback message. And finally, it was shown that interpersonal perception has been found to play an important role in how one behaves.

The following three sections will discuss (1) conclusions based on the statistical results of this study and 
their implications, (2) the limitations of this study, and (3) recommendations for future research.

\section{Discussion}

The present study's results were consistent with those cited earlier in that message characteristics significantly influenced responses to feedback. It is important to note, however, that previous studies (see Cusella, 1982; Duncan \& Bruwelheide, 1985; Ilgen et al., 1979; Jacobs \& Jacobs, 1973; Larson, 1986; Morran \& Stockton, 1980) have manipulated the valence of the message itself (positive vs. negative). In the present study, all of the feedback messages were in effect "negative" in that they all conveyed messages to the receiver that he/she had behaved inappropriately. What is unique about the present study is that it was the actual phrasing of the messages that was manipulated. From the results of the present research, it appears that within the context of a negative message, people are more likely to report an intention to change their behavior after having received a message that is constructively phrased. This finding is concurrent with the prescriptive literature that emphasizes it is not so much what you say, but how you say it (see Nelton, 1986; Dowst, 1987; Smith, 1987). 
The results of this study, however, did not indicate that a respondent would vary his/her behavior based upon perceived relationship. This result was surprising, given the research having to do with interpersonal perception, which posits that a person's behavior is "a function of his perceptions of the orientations held by others around him and of his orientation to them" (Mcleod \& Chaffee, 1973, p. 470). It would seem that one would have to be in total isolation not to have one's behavior affected in some way by his/her perceptions about others' perceptions of him/her. A more likely explanation of these findings might be that there is another variable interacting with the perceived relationship variable which is affecting the results. One such variable could be the receiver's self-concept. Previous studies have examined the self-concept of the receiver in relation to his or her responsiveness to feedback, particularly in relation to negative feedback. As Ilgen et al. report, "Shraugher and Rosenverg (1970) found that differences in responses to positive and negative feedback were related to self-esteem . . the results were consistent with the interpretation that persons with high self-esteem did not perceive negative feedback as clearly as positive" (p. 356). Jerhaps self-concept interacts with perceptions 
of others and perceptions of others' perceptions of oneself to affect response to feedback.

There is always the possibility, however, that perceived relationship has no effect upon responses to feedback; however, given the person perception literature, which asserts that our behavior is very much affected by what we believe others' perceptions to be, this notion seems rather unlikely. Much more research on this topic would need to be conducted before the perceived relationship variable could be ruled out as a contributing factor with regard to responsiveness to feedback.

\section{Limitations}

One limitation of this study involved the survey administration itself. Given the method of survey administration (the researcher was seldom present when the scales were actually being completed), there was no control for the amount of information about the purpose of the study given to the participants. In addition, since most of the respondents were either acquaintances or acquaintances of acquaintances, there was a lack of control in terms of the exact information the respondents received about the study. In most cases, the potential respondent was simply told that they were going to assist a graduate student in a study that she was conducting. 
Since the researcher was cautious not to reveal any of the hypotheses, it is assumed that a respondent's only additional knowledge of the study was the information he/she was given in the survey's cover sheet.

Another limitation of this study has to do with the population sampled. Over half of those responding to the scales were students in the field of communication studies. Since most communication studies curricula include some form of coursework having to do with interpersonal communication, a portion of those respondents sampled could have been familiar with research in the area of feedback. This in itself could have influenced their responses to the FRS.

The fact that there was not a specific time frame between the administration of Parts I and II of the study also served as a limitation. Some of the respondents received Part II within a day of turning in Part $I$, while others waited several days. This could have had an effect on how respondents completed the second packet of scales. Although each respondent was required to both read and respond to feedback messages in the second set of the scales, the source of those feedback messages was attributed to high and low relationship co-workers determined jin the first set of scales, which had been completed between one and four days before. One could 
argue that in between filling out the first and second set of scales, it is conceivable that the respondent could have changed his or her perception of the relationship with the person to whom the feedback was attributed.

\section{Recommendations}

While the present study did not measure actual behavior change, it did serve to develop a scale that proved reliable with respect to intentions to change behavior. As was stated earlier, while we do not know exactly how one will respond if feedback is "effective," certain actions lead us to assume someone will change his/her behavior as a result of feedback (e.g., reporting that he/she was glad someone brought this to his/her attention, reporting that he/she found the feedback to be helpful). This study served to develop a viable scale to measure one's intention to change behavior; future studies coula compare reported intention to change behavior to actual behavior change after feedback. For example, a future researcher could conduct a similar study to this one, having respondents complete Feedback Response Scales after reading feedback statements, then follow up by observing respondents and documenting any actual behavior change. Intentions to change could then be compared to actual observed behavior change. It would be very 
interesting to see how closely the two compare. Do we just report intentions to alter our behavior or do we actually follow through? Does it make a difference who the feedback comes from? These questions along with others could be addressed in such a study.

This study also served to collect self-concept data on individual respondents. Future researchers could examine the effect of self-concept on the perceived relationship variable. What effect does one's sense of self-concept have on perceived relationship? Does it offset or mediate the effect of perceived relationship?

Future studies could also investigate whether or not an individual's self-concept has any effect on how he/she responds to either constructively or destructively phrased feedback.

Another follow-up to this study could be an investigation that would utilize data collected in this study and examine it with respect to coorientation research. As Bacon (1986) states,

The process of coorientation results in one of four states based on measures of accuracy and agreement. Agreement refers to the similarity in the way both persons view the object. Accuracy is measured by how well both people predict the other's view of the object.

If the "object" is the respondent, it would be interesting to compare his/her view of him/herself (self-concept) to 
the perceived view of the person giving the feedback, to the actual view of the person giving the feedback. In other words, have the person giving the feedback write or state his/her actual perception of the receiver and compare that to the receiver's perception and to the receiver's self-concept. How does this affect feedback? Is a person more likely to report intention to change behavior when his/her perceptions of other's percetions of him/her are accurate? These and similar questions could be addressed by such a study. There is still concern, however, that there will always be a potential difference between self-report data and actual observed behavior. Future studies could consist of designs where researchers can observe actual behavior of respondents after they are given feedback messages. Ideally, researchers would have respondents describe situations from current interpersonal relationships, and design from these realistic elements of situations. This procedure would better insure that the participant could relate to the situation the feedback message described.

Although the results of this study were disappointing within the area of perceived relationship, very significant results were reported in the area of message characteristics. As noted above, and concurrent with the most recent 
prescriptive literature, it appears that within the context of a negative message, people are more likely to respond positively to certain message phrasing. Further research is needed, however, to determine if, in fact, people's perceptions of others' perceptions of them have an impact on their responses to both negative and positive feedback. 
REFERENCE LIST 
Annett, J. (1969). Feedback and human behavior. Baltimore: Penguin Books.

Ashford, S. J. (1986). Feedback-seeking in individual adaptation: A resource perspective. Academy of Management Journal, 29, 465-488.

Ashford, S. J. \& Cummings, L. L. (1983). Feedback as an individual resource. Organizational Behavior and Human Performance, $32,39 \overline{1-408}$.

Ashford, S. J. \& Cummings, L. L. (1985). Proactive feedback seeking: The instrumental use of the information environment. Journal of Occupational Psychology, 58, $67-80$.

Bacon, C. (1986). Toward a coorientation model and measure of organizational communication: Accuracy in superior-subordinate perceptions of socio-technical systems. Paper presented at the annual convention of the Speech Communication Association, Chicago, IL.

Bannister, B. D. (1986). Performance outcome feedback and attribution feedback: Interactive effects on recipient responses. Journal of Applied Psychology, $71(2), 203-210$.

Beck, C. E. \& Beck, E. A. (1986). The manager's open door and the communication climate. Business Horizons, $15,15-20$.

Bennett, J. C. \& Olney, R. J. (1986). Executive priorities for effective communication in an information society. Journal of Business Communication, 23, 13-23.

Bourne, L. E., Jr. \& Bunderson, C. V. (1963). Effects of delay of information feedback and length of post feedback interval on concept identification. Journal of Experimental Psychology, 65, 1-5.

Cliff, G. (1987). Managing organizational conflict. Management Review, 76, 51-53.

Conti, G. J. \& Fellenz, R. A. (1985). Giving constructive feedback: From theory to practice. Adult Literacy and Basic Education, 9, 5-10. 
Corbett, W. J. (1986). The communication tools inherent in corporate culture. Personnel Journal, 85, 71-73.

Cusella, L. P. (1982). The effects of source expertise and feedback valence on intrinsic motivation. Human Communication Research, 9, 17-32.

Dowst, S. (1985). Constructive criticism gets results, not resentment. Purchasing, 99, 1101 .

Duncan, P. K. \& Bruwelheide, L. R. (1985). Feedback: Use and possible behavioral functions. Journal of Organizational Behavior Management, $7,9 \overline{1-124}$.

Feinberg, M. R. (1985) . How to criticize effectively. (Management Psychology.) Business Magazine, 85, 112 .

Furnham, A. (1982). The message, the context and the medium. Language and Communication, $2,33-47$.

Gibb, J. (1961). Defensive communication. Journal of Communication, 11, 141-148.

Giffin, K. (1967). The contribution of studies of source credibility: A theory of interpersonal trust in the communicative process. Psychological Bulletin, 68, 104-120.

Goleman, D. (1988, July 31). Critiquing the way employers criticize. The San Jose Mercury News, pp. IL, $4 \mathrm{~L}$.

Greller, M. M. \& Herold, D. M. (1975b). Sources of feedback; A preliminary investigation. Organizational Behavior and Human Performance, $13,244-256$.

Grunig, J. E., Stamm, K. R., \& Tichenor, P. J. (1973). Applying the interpersonal perception model to the real world. American Behavioral Scientist, 16(4), 465-467.

Herold, D. M. \& Greller, M. M. (1977). Feedback: The definition of a construct. Academy of Management Journa1, 20(1), 142-147.

Hunsaker, P. I. \& Alessandra, J. (1987). Giving and getting feedback: we all know it's a crucial manager skill, but how exactly can we master its use? Working Woman, 12, 30-33. 
Ilgen, D. R., Fisher, C. D., \& Taylor, M. S. (1979). Consequences of individual feedback on behavior in organizations. Journal of Applied Psychology, 64 (4). 349-371.

Ilgen, D. R., Mitchell, T. R., \& Fredrickson, J. W. (1981). Poor performers: Supervisors' and subordinates' responses. Organizational Behavior and Human Performance, 27, 386-410.

Infante, D. A., Gorden, W. I. (1979). Subordinate and superior perceptions of self and one another: Relations, accuracy and reciprocity of liking. The Western Journal of Speech Communication, 43, 212-223.

Jacobs, M., Jacobs, A., Feldman, G., \& Cavior, N. (1973). Feedback II: "The credibility gap": Delivery of positive and negative emotional and behavioral feedback in groups. Journal of Consulting and Clinical Psychology, $\underline{41}(2), 215-223$.

Johnson, D. W. (1981). Reaching out: Interpersonal effectiveness and self actualization. Englewood Cliffs, NJ: Prentice-Hall.

Kastelen, L., Nickel, M., \& Mclaughlin, T. F. (1984). A performance feedback system: Generalization of effects across tasks and time with eighth grade English students. Education and Treatment of Children, $\underline{7}(2), 141-155$.

Laing, R. D., Phillipson, H., \& Lee, A. R. (1966). Interpersonal perception. New York: Springer Publishing Co.

Larson, J. R., Jr., Glynn, M. A., Fleenor, C. P., \& Scontrino, M. P. (1986). Exploring the dimensionality of managers performance feedback to subordinates. Human Relations, 39, 1083-2001.

Larson, J. R., Jr. (1986). Supervisor's performance feedback to subordinates: The impact of valence and outcome dependence. Organizational Behavior and human Decision Processes, $3 \overline{7}, 391-408$.

Luthans, F. \& Iarson, J. K. (1986). How managers really communicate. Human Relations, 39, 161-179.

Malinauskas, B. K. \& Clement, R. W. (1987). Performance appraisal interviewing for tangible results. Training and Development Journal, $41(2), 74-79$. 
McLeod, J. M. \& Chaffee, S. H. (1973). Interpersonal approaches to communication research. American Behavioral Scientist, 16(4), 469-499.

Morran, D. K. \& Stockton, R. A. (1980). Effect of selfconcept on group member reception of positive and negative feedback. Journal of Counseling Psychology, $27,260-267$.

Nelton, S. (1985). Feedback to employees can nourish your business. Nation's Business, 73, 62-63.

Olgilvie, J. R. \& Haslett, B. (1985). Communicating peer feedback in a task group. Human Communication Research, $12(1), 79-98$.

O'Reilly, C. \& Anderson, J. (1980). Trust and communication of performance appraisal information: The effect of feedback on performance and job satisfaction. Human Communication Research, 6, 290-298.

Scheff, T. (1967). Fưard a sociological model of concensus. American Sociological Review, 32, 32-46.

Smith, M. (1987). Feedback as a performance management technique. Management Solutions, 32, 20-30.

Stone, D. \& Stone, E. F. (1985). The effects of feedback consistency and feedback favorability on selfperceived task competence and perceived accuracy. Organizational Behavior and Human Decision Processes, 36, 167-176.

Sypher, B. D. \& Sypher, H. E. (1984). Seeing others as others see us: Convergence and divergence in assessments of communication behavior. Communication Research, 11 (1), 97-115.

Verderber, R. (1979). Communicate! Belmont, Ca: Wadsworth Publishing Co. 
APPENDICES 
APPENDIX A

SELF-PERCEPTION QUESTIONNAIRE 
PLEASE RESPOHO RY CIRCLIHG, THE APPROPRIATE LTITER(S)

VT-VERY POSITIVE P-POSITIVE ?-HEITHER FOSITIVE HOR NEGATIVE N-NEGATIVE. VN=VF.RY ME.GATIVE.

IF SOMEONE PERCEIVED HE AS:

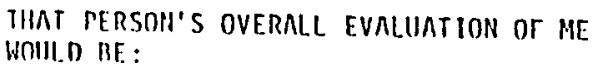
WOIII.D BE:

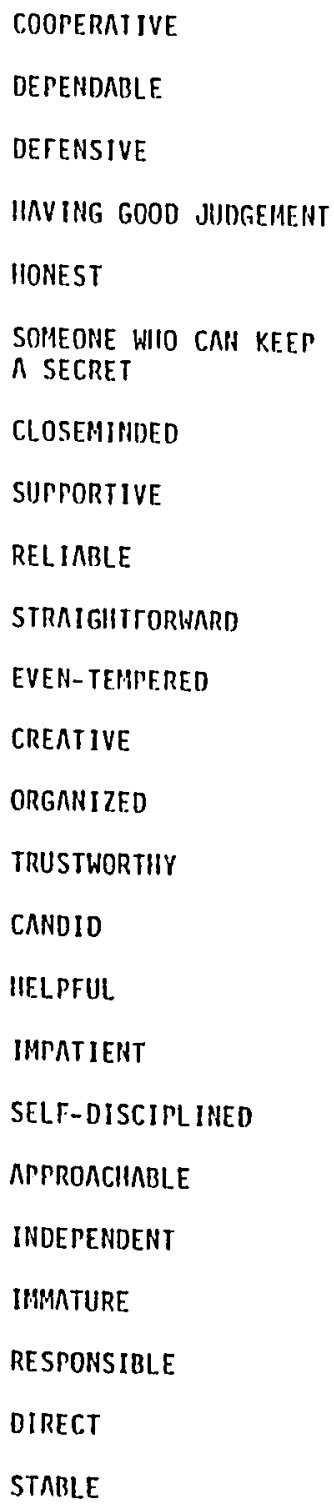


VI-VERY ROSIIIVE P-POSITIVE

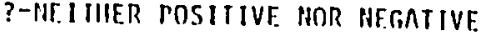
VH-VERY NEGATIVE N=VERY HEGATIVE

IT SOMEONE PERCEIVED ME AS:

IIIAT PTRSON'S OVERAI.L EVALUNIION OF ME WOIII.D BF :

UNCOUPERATIVE

COMPETERT

PRODHCTIVE

INNOVATIVE

NEAT

RIJOE

INTORMED

ACCOUNTABLE

THOUGIITFUL

$\begin{array}{lllll}\text { VP } & P & ? & \text { N } & \text { VN } \\ \text { VP } & P & ? & N & \text { VN } \\ \text { VP } & \Gamma & ? & N & \text { VN } \\ \text { VP } & \Gamma & ? & \text { N } & \text { VN } \\ \text { VP } & P & ? & \text { H } & \text { VN } \\ \text { VP } & \Gamma & ? & \text { N } & \text { VN } \\ \text { VP } & \Gamma & ? & \text { N } & \text { VN } \\ \text { VP } & \Gamma & ? & \text { N } & \text { VN } \\ \text { VP } & P & ? & \text { N } & \text { VN }\end{array}$

ONTE:

AGE : SEX: M $F$ 
APPENDIX B

PERCEIVED RELATIONSHIP QUESTIONNAIRE, PHASE I 
$\operatorname{FART} \lambda$

SOC. SF.C. NUMBER

PI,FASE RESPOHD BY CIRCISING TIIE APPROFRI $A T E$ IIETTERS

II GFIERAI, T PFRCFIUF MYSFI,F AS BEIIIG:

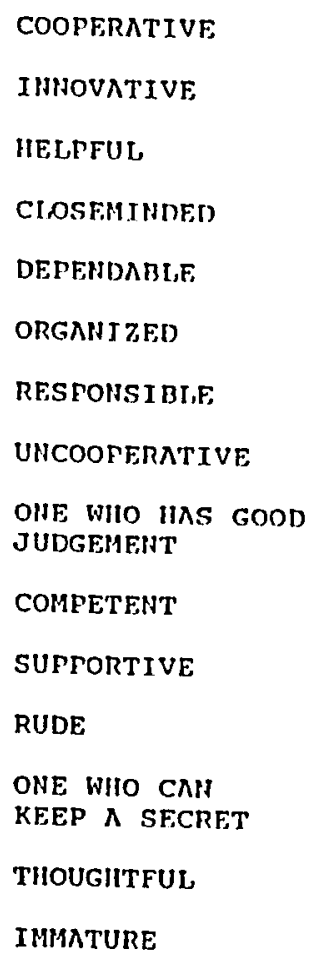

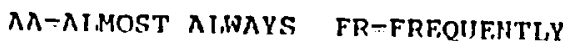
ST-SOHFT IMFS RA-RARELY AN-AIMOST NEVER

\begin{tabular}{|c|c|c|c|}
\hline גה & $F R$ & $5 \mathrm{~T}$ & $R A$ \\
\hline ג & FR & $\mathbf{S T}$ & $\mathrm{RA}$ \\
\hline ג & FR & ST & $\mathrm{R} \pi$ \\
\hline ג & FR & ST & $R \lambda$ \\
\hline ג & $F R$ & $\mathbf{S T}$ & $\mathrm{R} \lambda$ \\
\hline ג & FR & $\mathbf{S T}$ & $\mathrm{RA}$ \\
\hline$\lambda$ & FR & $S T$ & $\mathrm{RA}$ \\
\hline ג & FR & $\mathbf{S T}$ & $\mathrm{RA}$ \\
\hline ג & FR & ST & $\mathrm{RA}$ \\
\hline 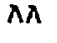 & FR & S'T & $\mathrm{RA}$ \\
\hline$\lambda$ & FR & ST & $\mathrm{R} \Lambda$ \\
\hline$\lambda \Lambda$ & FR & sT & $\mathrm{RA}$ \\
\hline$\Lambda \lambda$ & FR & $S T$ & $\mathrm{RA}$ \\
\hline ג & FR & ST & $\mathrm{RA}$ \\
\hline חג & FR & ST & $\mathrm{RA}$ \\
\hline
\end{tabular}


PART B

THINK OF 10 PEOPIE. IN YOUR WORK ENVIRONMENT WITII WIIOM YOU INIIERACT OIS $A$ DNILX BASIS.

PLENSE LTST IHEM BE.LW.

1.

2.

3.

4.

5.

6.

7.

8.

9.

10.

PLEASE GO ON TO THE NEXT FAGE... 
FART C

PLEASE COMPLFTE FACII OF THE FOLLOWIHG 5 SURVEYS $A S$ YOU

BELIEVE PERSOHS $2,1,6,8$, 10 FROM THE PREVIOUS PAGE WOUID

FII.T, TIIFM OUT ABOUT YOU IF IIF/SIIF. WF,PF TO COMPLFTE THE SURVEY. MLL 5 SURVEYS ARE IDENTICAL; FILL THE FIRST ONE OUT AS YOU THINK FERSON \#2 ON TIE LIST WOULD FILL IT OUT NBOUT YOU, THE SECOND ONE AS YOU THINK PERSON \# 1 WOULD FILL IT OUT IF HE/SHE WERE ASKED TO FILI, THE SURVEY OUT ABOUT YOU ETC...)

PLEASE GO OH TO THE NEXT PAGE... 
pART D

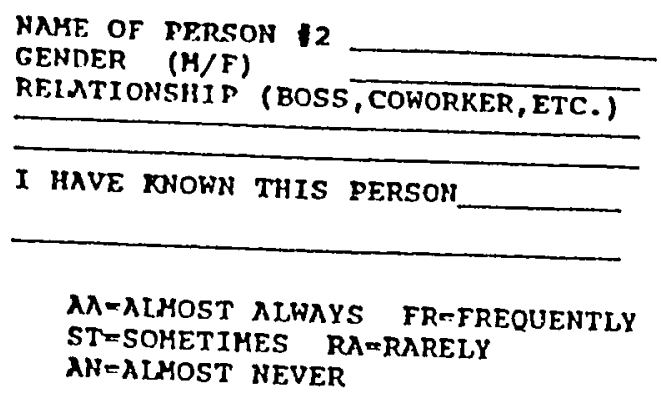

IX GENERAL, THR. FERSON WAKED ABOVE PERCETVES ME AS BEING:

\begin{tabular}{|c|}
\hline COOPERATIVE \\
\hline IWWOVATIVE \\
\hline HELPFUL \\
\hline CLOSEMINDED \\
\hline DEPENDABLE \\
\hline ORGANIZED \\
\hline RESPONSTBLE \\
\hline UNCOOPERATIVE \\
\hline $\begin{array}{l}\text { ONE WHO FAS GOOD } \\
\text { JUDGENENT }\end{array}$ \\
\hline COHPETENT \\
\hline SUPPORTIVE \\
\hline RODE \\
\hline $\begin{array}{l}\text { ONE WHO CAN KEEP } \\
\text { A SECRET }\end{array}$ \\
\hline THOUGRTFUL, \\
\hline IKAATURE \\
\hline
\end{tabular}

\begin{tabular}{|c|c|c|c|}
\hline$\lambda \Lambda$ & FR & $S T$ & $R A$ \\
\hline $\mathbf{A}$ & $F R$ & $S T$ & $R A$ \\
\hline $\boldsymbol{A}$ & $\mathbf{F R}$ & $\mathbf{S T}$ & $R A$ \\
\hline $\boldsymbol{\lambda A}$ & $\mathbf{F R}$ & ST & $R \lambda$ \\
\hline$A \lambda$ & FR & $\mathrm{ST}$ & $\mathbf{R A}$ \\
\hline$A \wedge$ & FR & $\mathbf{S T}$ & $R A$ \\
\hline$A A$ & $F R$ & ST & $\mathbf{R A}$ \\
\hline $\boldsymbol{\lambda} \mathbf{A}$ & $F R$ & ST & $R A$ \\
\hline$M$ & $\mathbf{F R}$ & ST & $\mathrm{RA}$ \\
\hline$\lambda \lambda$ & $\mathbf{F R}$ & ST & $R A$ \\
\hline $\boldsymbol{M}$ & $F R$ & ST & $R A$ \\
\hline $\mathbf{M}$ & $\mathbf{F R}$ & ST & $R A$ \\
\hline$\lambda \lambda$ & FR & ST & $\mathbf{R A}$ \\
\hline $\boldsymbol{\lambda} \boldsymbol{\lambda}$ & $F R$ & $\mathbf{S T}$ & RA \\
\hline$\lambda \lambda$ & $\mathbf{F R}$ & ST & $\mathbf{R A}$ \\
\hline
\end{tabular}

PLEASE GO ON TO THE NEXT PAGE... 


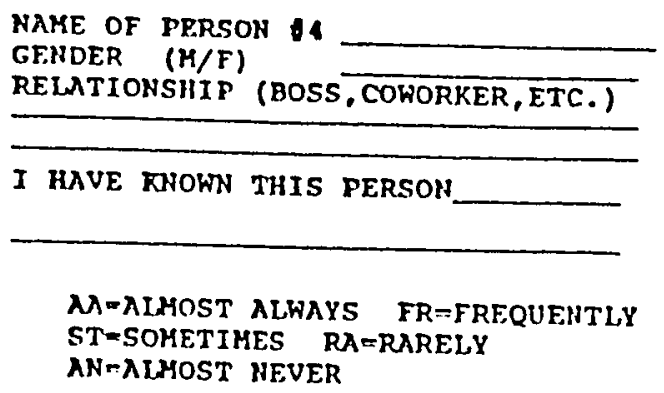

IN GFNFRN, TTR, PRRSOH HAHED ABOVE PERCFIVF.S KF AS BEING:

COOPERATIVE
INNOVATIVE
HELPFUL
CLOSEMINDED
DEPENDABLE
ORGAYIZED
RESPONSIBLE
UNCOOPERATIVE
ONE WHO HAS GOOD
JUDGEMENT
COHPETENT
SUPPORTIVE
RUDE
ONE WHO CAN KEEP
A SECRET
THOUGHTFUL
IKHATURE
THE

\begin{tabular}{|c|c|c|c|}
\hline$M$ & FR & ST & $\mathbf{R A}$ \\
\hline$\lambda A$ & FR & ST & RA \\
\hline AA & FR & $S T$ & RA \\
\hline$M A$ & $\mathrm{FR}$ & $S T$ & RA \\
\hline $\boldsymbol{M}$ & FR & ST & $R A$ \\
\hline$M A$ & FR & ST & $\mathbf{R A}$ \\
\hline$M$ & $\mathbf{F R}$ & $\mathbf{S T}$ & RA \\
\hline $\boldsymbol{\lambda} \boldsymbol{\lambda}$ & FR & ST & $R A$ \\
\hline $\boldsymbol{A} A$ & FR & ST & $\mathbf{P A}$ \\
\hline$\lambda \lambda$ & $\mathbf{F R}$ & ST & RA \\
\hline AA & FR & ST & RA \\
\hline$\lambda A$ & $\mathbf{F R}$ & ST & RA \\
\hline$\lambda \lambda$ & FR & $\mathbf{S T}$ & $\mathbf{R A}$ \\
\hline$\lambda \boldsymbol{A}$ & $\mathbf{F R}$ & ST & $\mathbf{R A}$ \\
\hline AA & $F_{R}$ & $\mathbf{S T}$ & $\mathrm{RA}$ \\
\hline
\end{tabular}


NAME OF PPRSON 6

GENDER (M/F)

REIATIONSHIP (BOSS,COWORKER, ETC.)

I HAVE RNOWN THIS FERSON

ALOST ALWAYS FR=FREQUENTLY

ST=SOMETIMES RA=RARELY

$\lambda N=A$ HOST NEVER

IN GENERAT, THE RERSON NAKED ABOVE PERCEIVES KE

AS BEING:

COOPERATIVE
INNOVATIVE
HELPFUL
CIOSEMINDED
DEPENDABIE
ORGANIZED
RESPONSIBLE
UNCOOPERATIVE
ONE HHO HAS GOOD
JUDGEHENT
COMPETENT
SUPPORTIVE
RUDE
ONE GHO CAN REEP
A SECRET
THOUGHTFUL
IRHATURE

\begin{tabular}{|c|c|c|c|}
\hline$\lambda \lambda$ & FR & $\mathbf{S T}$ & $\mathrm{RA}$ \\
\hline$\lambda \Lambda$ & FR & ST & $\mathbf{R A}$ \\
\hline$\lambda A$ & FR & $\mathbf{S T}$ & $R A$ \\
\hline$\lambda \lambda$ & $\mathbf{F R}$ & ST & $R A$ \\
\hline$\lambda \Lambda$ & FR & ST & $\mathrm{RA}$ \\
\hline$\lambda$ & FR & ST & RA \\
\hline$\lambda \boldsymbol{\lambda}$ & FR & ST & $R A$ \\
\hline$\lambda A$ & $F R$ & ST & RA \\
\hline$\lambda \boldsymbol{\lambda}$ & $F R$ & ST & $\mathbf{R A}$ \\
\hline
\end{tabular}

AA FR ST RA AN

$\begin{array}{lllll}M & F R & S T & R A & A N\end{array}$

$\begin{array}{lllll}\lambda \boldsymbol{N} & \text { TR } & \mathrm{ST} & \mathrm{RA} & \mathrm{AN}\end{array}$

AA FR ST RA AN

$\begin{array}{lllll}M A & F R & R T & \text { NH }\end{array}$

AA FR ST RA AN

PLEASE GO ON TO THE NEXT PAGE... 


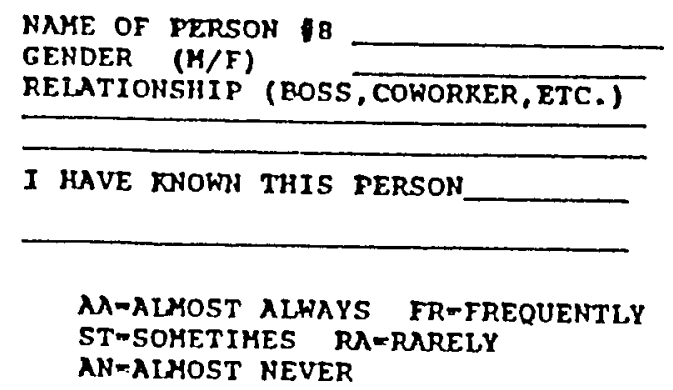

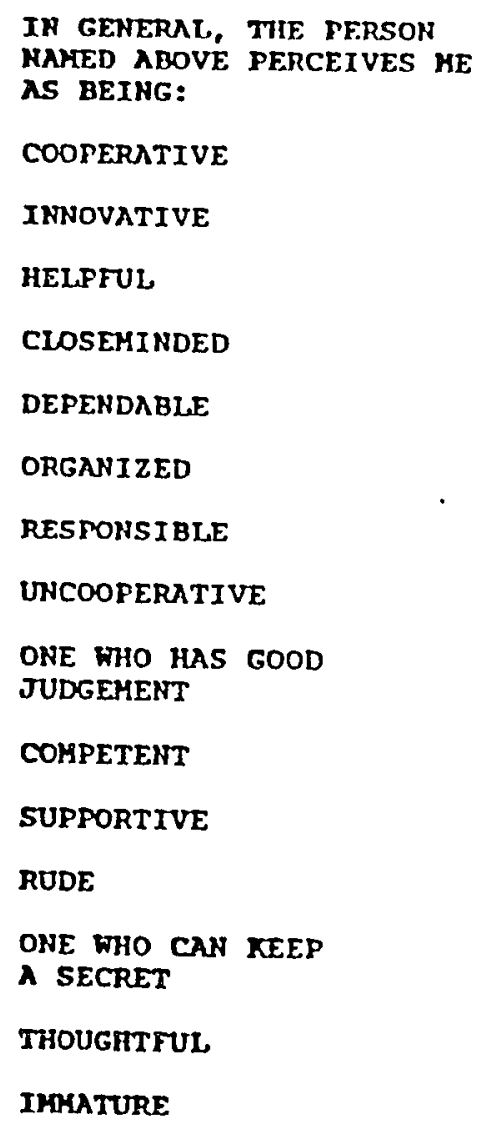

\begin{tabular}{|c|c|c|c|}
\hline $\boldsymbol{M}$ & $\mathrm{FR}$ & ST & $R \wedge$ \\
\hline$A \wedge$ & $\mathbf{F R}$ & ST & $R A$ \\
\hline $\mathbf{A A}$ & $\mathrm{FR}$ & ST & $R A$ \\
\hline$A \lambda$ & FR & ST & $R \wedge$ \\
\hline$M$ & FR & ST & $\mathbf{R A}$ \\
\hline$A \Lambda$ & FR & $\mathbf{S T}$ & $\mathbb{R A}$ \\
\hline$A A$ & FR & ST & RA \\
\hline $\boldsymbol{M A}$ & $\mathbf{F R}$ & ST & $\mathbf{R A}$ \\
\hline$\lambda \lambda$ & $F R$ & ST & $\mathbf{R A}$ \\
\hline$A A$ & $F R$ & ST & $\mathrm{RA}$ \\
\hline $\boldsymbol{A A}$ & $F R$ & $S T$ & $\mathrm{P} \lambda$ \\
\hline $\boldsymbol{\lambda \Lambda}$ & FR & ST & $\mathbf{R A}$ \\
\hline AA & $\mathrm{FR}$ & ST & $\mathbf{R A}$ \\
\hline $\mathrm{AA}$ & FR & ST & $\mathbf{R A}$ \\
\hline AA & FR & ST & RA \\
\hline
\end{tabular}

PLEASE Go ON TO THE NEXT PAGE... 
NAME OF PFRSON 10

GEHDFR (N/F)

REI.ATIONSIIIP (BOSS, COWORKER, ETC.)

I HAVE KNOWH TUIS PERSON

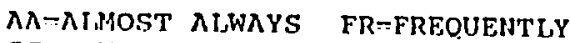
ST-SOMETIMES RA-RARFI,Y

$\lambda \mathrm{H}=\Lambda$ IMOST NEVFR

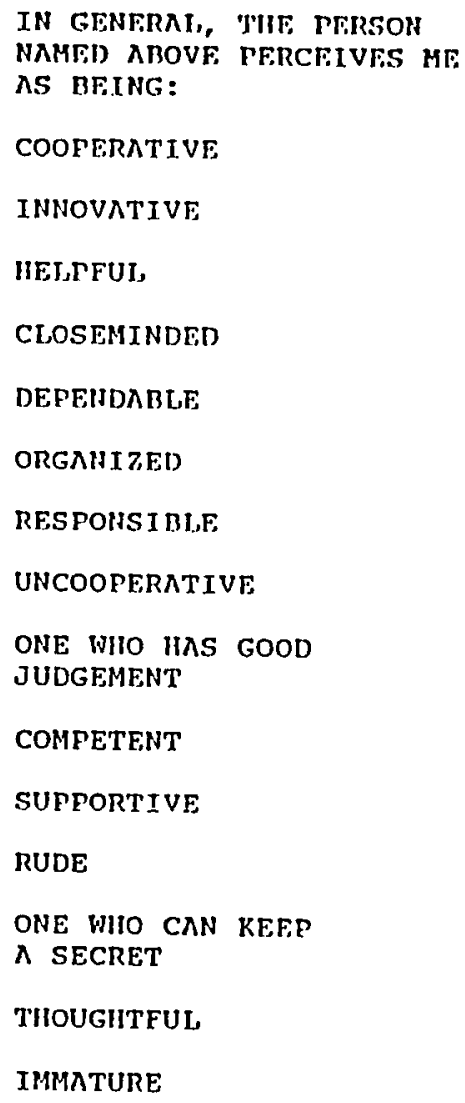

\begin{tabular}{|c|c|c|c|c|}
\hline חג & FR & ST & $R \wedge$ & NN \\
\hline$\lambda$ & FR & ST & $R \Lambda$ & $\Lambda N$ \\
\hline תו & FR & ST & $\mathrm{R} \Lambda$ & $\Lambda N$ \\
\hline$n \lambda$ & FR & ST & $R \Lambda$ & $\lambda N$ \\
\hline$\Lambda \lambda$ & FR & ST & $\mathrm{R} \lambda$ & $\lambda N$ \\
\hline$\pi$ & FR & $S T$ & $\mathrm{RA}$ & $\lambda N$ \\
\hline$\lambda \pi$ & FR & ST & $R \wedge$ & NN \\
\hline$n \lambda$ & FR & ST & $R A$ & $\lambda N$ \\
\hline הא & $\mathrm{FR}$ & ST & $\mathrm{R} \lambda$ & $\lambda N$ \\
\hline$\lambda$ & $\mathrm{FR}$ & ST & $\mathrm{R} \lambda$ & $A N$ \\
\hline$\lambda \lambda$ & $\mathrm{FR}$ & $S T$ & $\mathrm{R} \lambda$ & AN \\
\hline$\lambda \pi$ & FR & ST & $\mathbf{R A}$ & AN \\
\hline$\lambda \lambda$ & FR & ST & $\mathrm{R} \pi$ & $\lambda N$ \\
\hline$\pi$ & $\mathrm{FR}$ & $S T$ & $\mathrm{Rn}$ & AN \\
\hline$n \pi$ & FR & $\mathbf{S T}$ & $\mathrm{RA}$ & \\
\hline
\end{tabular}

PLFASE MAKE SURE YOUR SOCTAL SECURITY NUMBER IS ON THE FIRST PAGE. 
APPENDIX C

FEEDBACK MESSAGE INDICATOR 
PLEASE READ THE FOLLOWING FEEDBACK MESSAGES, THEN PLACE AN $X$ ON THE SCALE THAT FOLLOWS EACH MESSAGE TO INDICATE WHETHER YOU BELIEVE THE MESSAGE. IS CONSTRUCTIVE OR DESTRUCTIVE. PLACE THE $X$ IN ACCOROANCE WITII HOW CONSTRUCTIVE OR DESTRUCIIVE YOU FEEL THE MESSAGE IS (IE: THE MORE CONSTRUCTIVE. THE CLOSER YOU WOULD PLACE THE $X$ TO THE 7 MODULE).

You lost that report we need for the meeting and I had to spend my lunch hour making a new copy. Needless to say.
I'm pretty upset.

VERY

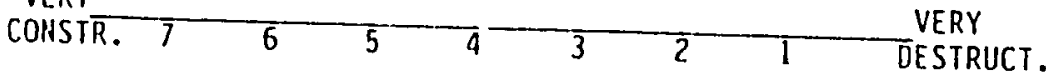

I don't of ten hear you introduce new ideas about how you can increase productivity within your work area: Without your input I feel like the whole burden falls on me.

VERY

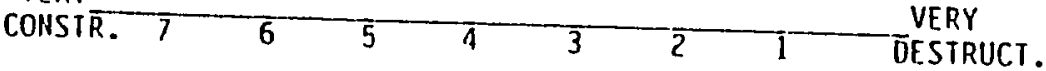

You've been 10 to 15 minutes late for our last three meet ings. When I have to sit and wait, I get angry and that gets in the way when we do start the meeting.

VERY

CONSTR. 7 T 6 6 5 VERY

You really screwed up by losing that report. Your desk is such a mess you can never find anything. You should be more careful your desk like that!

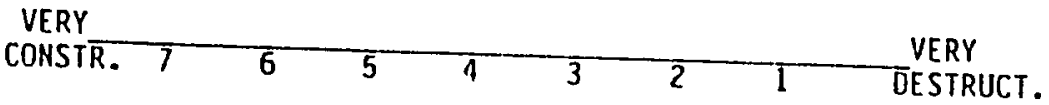

You don't seem to work well with anyone. Every time you are working on a team project, the other group members complain about you- you're getting a bad reputation!

VERY

CONSTR. $7 \begin{array}{llllll} & & & \text { VERY } \\ \text { DESTRUCT. }\end{array}$


You never make any suggestions or bring up any new ideas at our monthly staff meet ings: Can't you think of any?

VERY

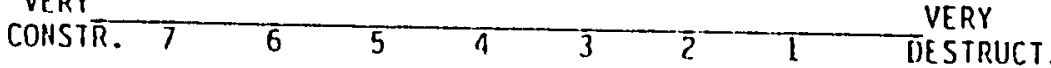

No one can ever count on you. You're never where you say you're gonna be. Is your time more valuable than ours?

VERY

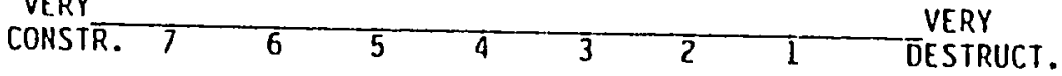

I've been feeling uncomfortable because twice lately you have snapped at me when I have asked you for something. Is it my imagination, or have you been tense lately?

VERY

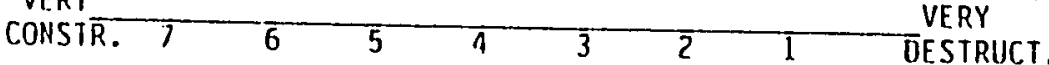

You can't be trusted with any confidential information. I just found out that you blabbed the news about the new Vice President. You knew that was supposed to be just between you and I.

VERY

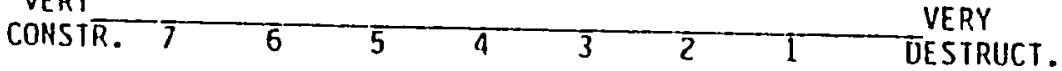

You've been impossible lately. Everyone is complaining about what a grouch you've been lately.

VERY

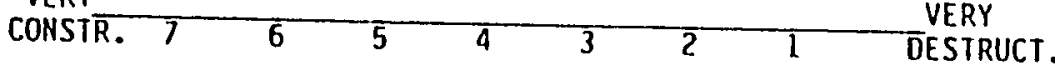

Mary just told me you told her we were getting a new Vice President. This concerns me because when I told you this news I asked that you not mention it to anyone else.

VERY

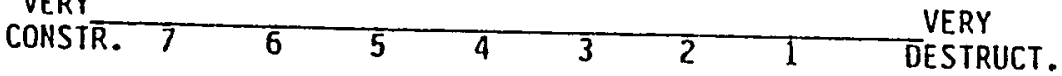

I found it difficult to work with you on the profect last week. Several times you insisted on having the group use your ideas. I feit frustrated.

VERY

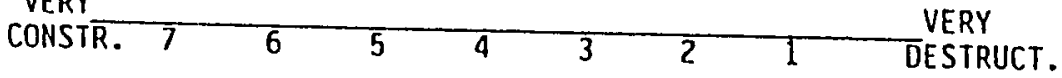


APPENDIX D

PRELIMINARY FRS QUESTIONNAIRE: CONSTRUCTIVELY PHRASED 


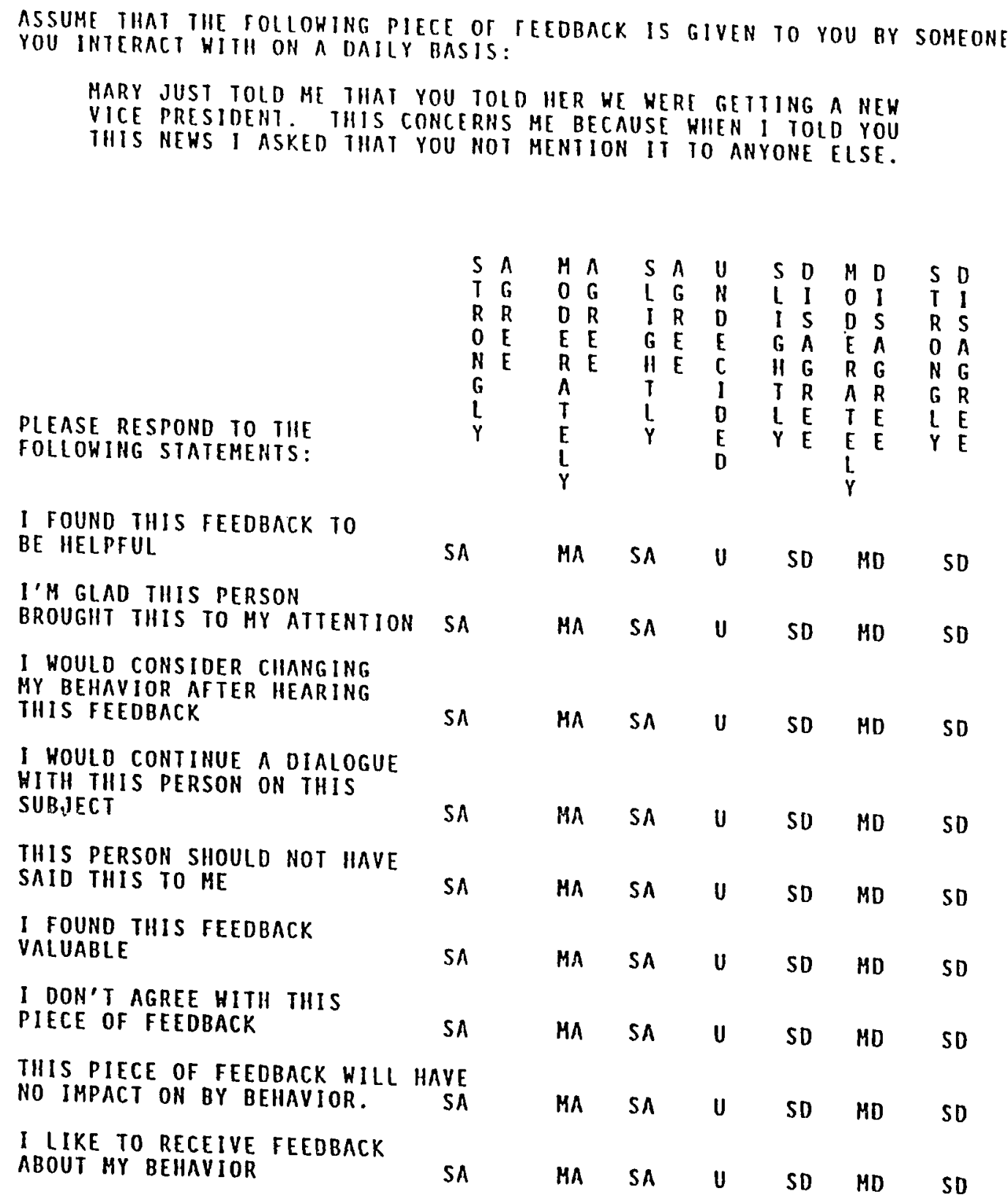


THIS TEEDBACK WOULO BE USELESS TO ML

PEOPLE SHOULD KEEP THINGS

LIKE THIS TO THEMSELVES

1 HOULO CONTINUE TALKING

TO THIS PERSON TO FIND OUT

WHAT PROMPTEO THEM IO SAY

THIS TO ME

I HILL TAKE THIS FEEDBACK

INTO CONSIDERATION THE NEXT

TIME I AM IN A SITUATION LIKE

TIIE ONE DESCRIBED ABOVE

THIS PIECE OF FEEDBACK

WOULD BE OF USE TO ME

$\begin{array}{lllllll}S A & H A & S A & U & \text { SD } & M D & \text { SD } \\ \text { SA } & M A & S A & U & \text { SD } & M D & \text { SD }\end{array}$

SA MA SA U SD MD SO

I NOULD NVOID FURTHER INTER.

ACTION HITH TIIIS PERSON

I HOULD ACT DIFFERENTLY

IIAVING RECEIVED THAT PIECE

OF FEEDBACK

I WAS OFFENDED BY TIIIS

PIECE OF FEEDBACK

TIIIS FEEDBACK DOESN'T

APPLY TO ME

SA MA SA U SD MD SD

SA MA SA U SO MO SO

SA MA SA U SD MD SD

TIIIS FEEDBACK HURT MY

FEELINGS

I LIKE TO RECEIVE FEEDBACK

SA MA SA U SD MO SD

THIS HAS GOOD FEEDBACK

THIS FEEDBACK COULD HAVE

BEEN PHRASED BETTER

SA MA SA U SD MD SO

TIIIS PIECE OF FEEDBACK

HILL HAVE NO BEARING

ON MY FUTURE BEHAVIOR

SA HA SA U SD MD SO

SA MA SA U SO MO SD

SA MA SA U SD MD SD

SA MA SA $U$ SD MD SD

SA HA SA U SD HD SD

SA HA SA U SD MO SD 
APPENDIX E

PRELIMINARY FRS QUESTIONNAIRE: DESTRUCTIVELY PHRASED 


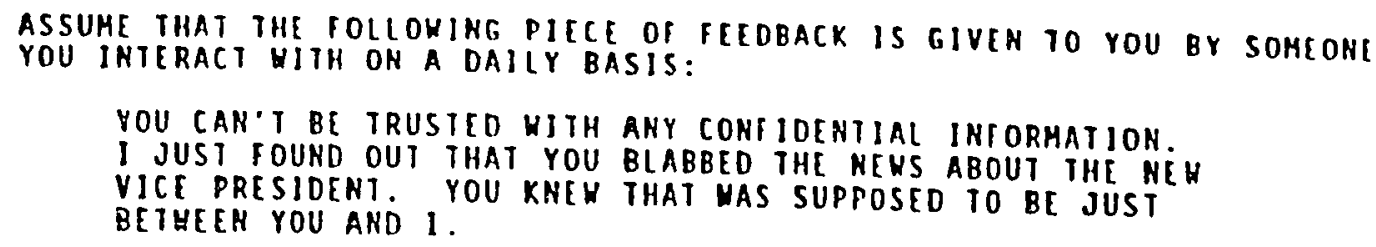

PLEASE RESPOND TO THE

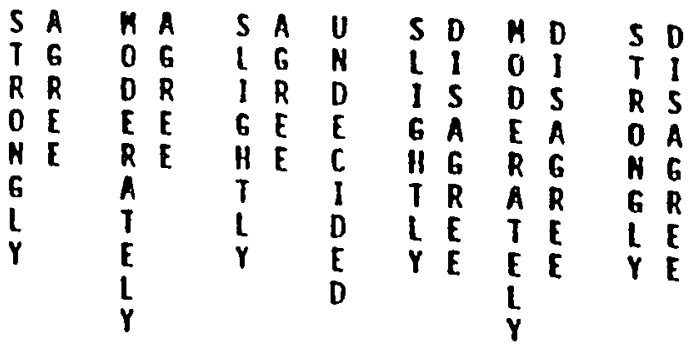

FOLLOHING STATEHENTS:

$\begin{array}{lllllll}\text { SA } & \text { HA } & \text { SA } & U & \text { SD } & \text { HD } & \text { SD } \\ \text { SA } & \text { HA } & S A & U & \text { SD } & \text { HD } & \text { SD } \\ \text { SA } & \text { MA } & \text { SA } & U & \text { SD } & \text { HD } & \text { SD } \\ \text { SA } & \text { MA } & \text { SA } & U & \text { SD } & \text { HD } & \text { SD } \\ \text { SA } & \text { MA } & \text { SA } & U & \text { SD } & \text { HD } & \text { SD } \\ \text { SA } & \text { MA } & \text { SA } & U & \text { SD } & \text { HD } & \text { SD } \\ \text { SA } & \text { MA } & \text { SA } & U & \text { SD } & \text { MD } & \text { SD } \\ \text { SYE } & & & & & & \\ \text { SA } & \text { MA } & \text { SA } & U & \text { SD } & \text { MD } & \text { SD }\end{array}$

I FOUND THIS FEEDBACK TO BE HELPFUL

I'K GLAD THIS PERSOK

BROUGHT THIS TO MY ATTENTION

1 NOULD CONSIDER CHANGIHG MY BEHAYIOR AFTER HEAR ING

THIS FEEDBACK

I VOULD COHTINUE A DIALOGUE YITH THIS PERSOH OH THIS

SUBJECT

THIS PERSON SHOULD HOT HAVE SAID THIS TO HE

\section{FOUHD THIS FECDBACK VALUABLE}

I DON'T AGREE VITH THIS

PIECE OF FEEDBACK

THIS PIECE OF FEEDBACK HILL HAYE HO IHPACT OH BY BEHAVIOR. 


\begin{tabular}{|c|c|c|c|c|c|c|c|}
\hline USELESS TO KE & SA & MA & SA & U & SD & KO & SD \\
\hline $\begin{array}{l}\text { PLOPLE SHOULO KEEP THINGS } \\
\text { LIKE THIS TO THEHSELVES }\end{array}$ & $S A$ & MA & SA & $\mathbf{U}$ & SD & MD & SD \\
\hline $\begin{array}{l}\text { I HOULD CONIIAUE TALKIHG } \\
\text { TO THIS PERSON TO FIND DUT } \\
\text { YHAT PROMPIED THEH TO SAY } \\
\text { THIS TO KE }\end{array}$ & $S A$ & MA & SA & u & SD & MD & SD \\
\hline $\begin{array}{l}\text { I WILL TAKE THIS FECDBACK } \\
\text { INTO COHSIDERATION THE HEXT } \\
\text { TIHE I AK IN A SITUATION LIKE } \\
\text { THE OHE DESCRIBED ABOVE }\end{array}$ & SA & MA & SA & $u$ & SD & KD & SD \\
\hline $\begin{array}{l}\text { THIS PIECE OF FCEDBACK } \\
\text { WOULD BE OF USE TO ME }\end{array}$ & SA & MA & SA & $\mathbf{u}$ & SD & HD & SD \\
\hline $\begin{array}{l}1 \text { HOULO AVOID FURTHER INTER- } \\
\text { ACTIOH YITH THIS PERSOH }\end{array}$ & $s A$ & MA & SA & $\mathbf{U}$ & SD & MD & SD \\
\hline $\begin{array}{l}\text { I YOULD ACT DIFFERENTLY } \\
\text { HAVIHG RECEIVED THAT PIECE } \\
\text { OF FEEDBCK }\end{array}$ & SA & MA & $5 \Lambda$ & $\mathbf{U}$ & SD & MD & SD \\
\hline $\begin{array}{l}\text { I WAS OFFENDED BY THIS } \\
\text { PIECE OF FEEDBACK }\end{array}$ & SA & MA & SA & $\mathbf{U}$ & SD & MD & SD \\
\hline $\begin{array}{l}\text { THIS FEEDBACK DOESH'T } \\
\text { APPLY TO ME }\end{array}$ & SA & MA & SA & $\mathbf{U}$ & SD & HD & SD \\
\hline $\begin{array}{l}\text { THIS FEEDBACK HURT NY } \\
\text { FEELIHGS }\end{array}$ & SA & NA & $5 A$ & $\mathbf{U}$ & SD & ND & SD \\
\hline I LIKE TO RECEIVE TEEDBACK & SA & MA & $\mathbf{s A}$ & $\mathbf{U}$ & so & HD & SD \\
\hline THIS YAS GOOD IEEOSACK & SA & $\tilde{H} \hat{A}$ & $5 \AA$ & $u$ & SD & MD & SD \\
\hline $\begin{array}{l}\text { THIS FEEDBACK COULD HAVE } \\
\text { BEEN PHRASED BETIER }\end{array}$ & SA & MA & SA & $\boldsymbol{v}$ & SD & MD & SD \\
\hline $\begin{array}{l}\text { THIS PIECE OF FEEDBACK } \\
\text { YILL HAYE HO BEARIHG } \\
\text { ON HY FUTURE BEHAYIOR }\end{array}$ & SA & $M A$ & SA & $\mathbf{U}$ & SD & KD & SD \\
\hline
\end{tabular}


APPENDIX F

PERCEIVED RELATIONSHIP QUESTIONNAIRE, PHASE II 
PART II

SOC. SEC. NUKBER

THE FOLLOWING PAGES CONTATN POUR STATEHENTS. PLEASE READ EACH STATEKENT, THEN RESPOND TO THE QUESTIONS THAT DIRECTLY FOLLOW. THE PERSON LISTED AT THE TOP OF EACH SECTION WILL BE ONE OF THE TEN PEOPLE YOU LTSTED IN PART I AS BEING IN YOUR WORK ENVIRONMENT. PLEASB RESTOND TO BACR SET OF QUESTIONS EXACTLX AS yOU wOULD IP THB PERSON IISTED RAD RCTVALLT SATD THIS TO YOO.

THANK YOU POR YOUR COOPERATION!!

PLEASE Go ON TO THE NEXT PAGE... 


\section{ASSUHE THAT THE FOLLOHING PIECE OF FEEDBACK IS GIVEN TO YOU BY MARY \\ YOU'VE BEF 10 TO 15 MTHUTRS IATE FOR OUR IAST THREE KEETINGS.
WTIFN I RAVE TO SIT AND DATT. I CET AHGRY WAY MIEN WE DO START TIE KEETING.}

PLEASE RESPOND TO TTR FOLLOKING STATFAENTS

AS YOU WOULD IP MARy

RAD SAID THE ABOVE

TO YOU:

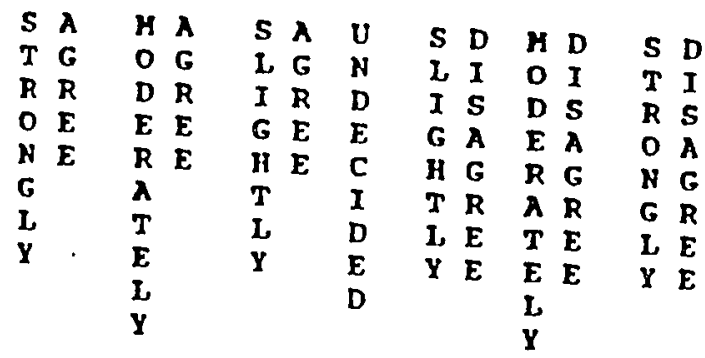

I FOUND THIS FEEDBACR TO BE HELPFUL

I'H GLAD THIS PERSON BROUGHT THIS TO HY ATTENTION SA

THIS FEEDBACK HURT HY FEELTNGS

I WOULD CONTINUE A DIALOGUE WITH THIS PERSON ON THIS SUBJECT

THIS PERSON SHOULD NOT HAVE EAID THIS TO ME

$\begin{array}{lllllll}\text { SA } & \text { KA } & \text { SA } & U & \text { SD } & \text { KD } & \text { SD } \\ \text { SA } & \text { HA } & S A & U & \text { SD } & \text { KD } & \text { SD } \\ \text { SA } & \text { HA } & \text { SA } & U & \text { SD } & \text { HD } & \text { SD } \\ \text { SA } & \text { KA } & \text { SA } & U & \text { SD } & \text { KD } & \text { SD } \\ \text { SA } & \text { HA } & \text { SA } & U & \text { SD } & \text { HD } & \text { SD }\end{array}$

PLEASE go ON To TIE hEXT PAgE... 


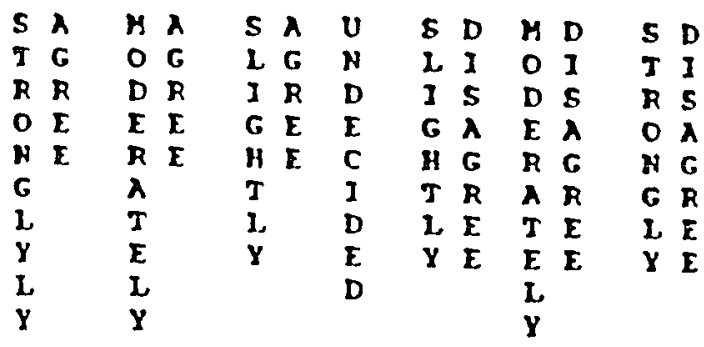

PEOPLE SHOULD KEEF THINGS

LIKE THIS TO THEHSELVES

$\begin{array}{lllllll}\text { SA } & \text { MA } & \text { SA } & U & \text { SD } & \text { MD } & \text { SD } \\ \text { SA } & \text { MA } & \text { SA } & U & \text { SD } & \text { HD } & \text { SD } \\ \text { SA } & \text { MA } & \text { SA } & U & \text { SD } & \text { MD } & \text { SD } \\ \text { SA } & \text { HA } & \text { SA } & U & \text { SD } & \text { MD } & \text { SD } \\ \text { SA } & \text { HA } & \text { SA } & U & \text { SD } & \text { HD } & \text { SD } \\ \text { SA } & \text { MA } & \text { SA } & U & \text { SD } & \text { MD } & \text { SD } \\ & & & & & & \\ \text { SA } & \text { HA } & \text { SA } & U & \text { SD } & \text { KD } & \text { SD }\end{array}$

Please gol oN to THE NEXT PAGE... 
ASSUME THAT THE FOLLOWING PIECE OF FEEDBACK IS GIVEN TO YOU BY FRED

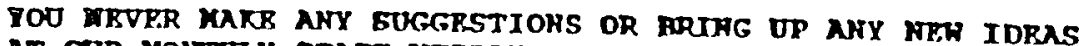
AT OUR HONTHLY STAPP MERTIKGS; CAK'T YOO THIFK OF AFY?

PLEASB RRSPOND TO TTB FOTLOFTHG STATBNEATS

AS YOU WOULD IP FRED

GND SAID TRB ABOVE

TO TOU:

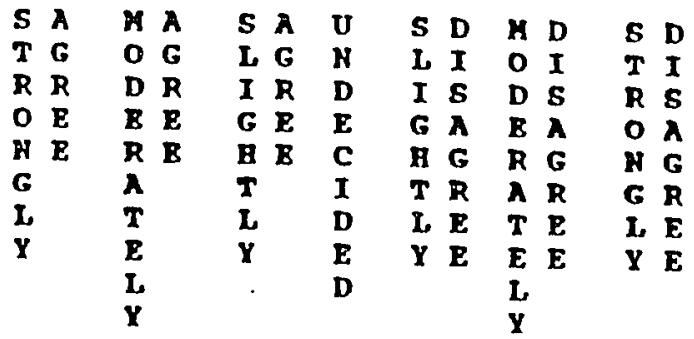

I FOUND THIS FEEDBACR TO BE RELPFUL

SA MA SA U SD MD SD

I'H GLAD THIS PERSON

RROUGET TRIS TO MY ATTENTION SA

SA MA SA U SD HD SD

MHIS FEEDBACK HURT KY

REELIHGS

$\begin{array}{lllllll}\text { GA } & \text { HA } & \text { SA } & \text { U } & \text { SD } & \text { KD } & \text { SD }\end{array}$

I WOULD CONTINUE A DIALOGUE HITH THIS PERSON ON THIS SUBJECT

$\begin{array}{lllllll}\text { SA } & \text { KA } & \text { SA } & \mathbf{0} & \text { SD } & \text { KD } & \text { SD }\end{array}$

THIS PERSON SHOULD HOT RAVE SAID THIS TO $\mathrm{KE}$

MA SR $\mathbf{D}$ SD HD 
PEOPLE SHOULD KEEP THIHGS LIKE THIS TO THEMSELVES

\begin{tabular}{|c|c|c|c|c|c|}
\hline $\mathbf{S A}$ & $\mathrm{MH}$ & $\mathbf{s} \boldsymbol{\lambda}$ & $\mathbf{u}$ & SD & HO \\
\hline$s \lambda$ & MA & SA & $\mathbf{U}$ & SD & HD \\
\hline $\mathbf{s} \boldsymbol{x}$ & KA & $5 \lambda$ & $\mathbf{U}$ & SD & HD \\
\hline$s \lambda$ & MA & $s \lambda$ & $\mathbf{U}$ & SD & HD \\
\hline$S A$ & MA & SA & $\mathbf{U}$ & SD & หD \\
\hline$S A$ & MA & SA & $\mathbf{U}$ & SD & KD \\
\hline$S \lambda$ & MA & $5 A$ & $\mathbf{U}$ & SD & HD \\
\hline
\end{tabular}

PLFASE Go ON to the hEXT PAge... 
ASSUME THAT TIE FOLLOWING PIECE OF TEEDBACK IS GIVEN TO YOU BY FRED

WARY JUST TOID HE THAT YOU TOIJ) HER WE HERP GETTING A HEW

THIS NEWS I AST THIS CONCFRNS ME BECAUSE WIEN I TOLD YOU

THIS NEWS I ASRED THAT YOO HOT KENTION IT TO ANYONE ELSE.

PLEASE RESTOND TO TTE

POLIOWTHG STATEAENTS

AS YOU YOULD IF

$$
\text { EREI }
$$

FAD SAID THE ABOVE

TO YOO:

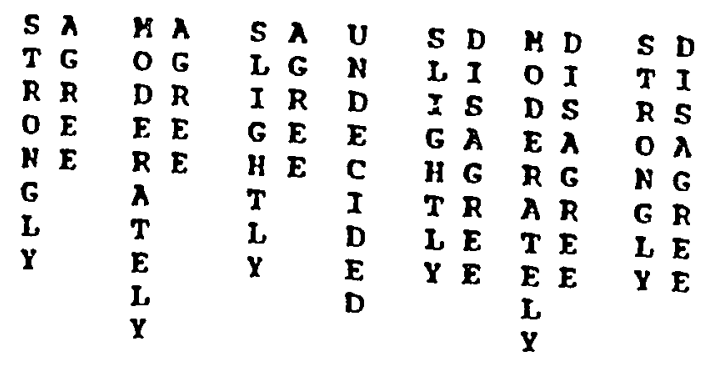

I FOUND THIS FEEDBACK TO BE RELPFUL

I'K GLAD THIS PERSON BROUGHT THIS TO HY ATTENTION THIS FEEDBACR HURT HY FEELINGS

I WOULD CONTINUE A DIALOGUE WITH THIS PERSON ON THIS SUBJECT

THIS PERSON SHOULD NOT FRVE SAID THIS TO ME

$\begin{array}{lllllll}\text { SA } & \text { KA } & \text { SA } & U & \text { SD } & \text { HD } & \text { SD } \\ \text { SA } & \text { KA } & \text { SA } & U & \text { SD } & \text { HD } & \text { SD } \\ \text { SA } & \text { KA } & \text { SA } & U & \text { SD } & \text { KD } & \text { SD } \\ \text { SA } & \text { KA } & \text { SA } & \mathbf{U} & \text { SD } & \text { HD } & \text { SD } \\ \text { SA } & \text { HA } & \text { SA } & U & \text { SD } & \text { KD } & \text { SD }\end{array}$

PIEASE so on To ItRe HERT PAGE... 


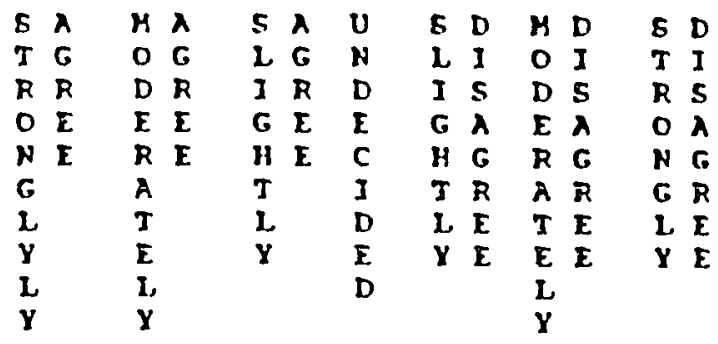

\begin{tabular}{|c|c|c|c|c|c|c|}
\hline LIKE THIS TO THERSELVES & SA & MA & sA & $\mathbf{u}$ & SD & MD \\
\hline $\begin{array}{l}\text { THIS FEEDBACK COULD HAVE } \\
\text { BEEN PHPASED BETTER }\end{array}$ & SA & MA & SA & $\mathbf{v}$ & SD & HD \\
\hline $\begin{array}{l}\text { THIS PIECE OF FEEDBACK } \\
\text { WOULD BE OF USE TO ME }\end{array}$ & SA & MA & 5A & $\mathbf{v}$ & SD & MD \\
\hline $\begin{array}{l}\text { I WOULD ACT DIFFERENTLY } \\
\text { HAVING RECEIVED THAT PIECE } \\
\text { OF FEEDBACK }\end{array}$ & SA & KA & SA & $\mathbf{u}$ & SD & MD \\
\hline $\begin{array}{l}\text { I WAS OFFENDED BY THIS } \\
\text { PIECE OF FEEDBACR }\end{array}$ & Sin & MA & SA & $\mathbf{u}$ & SD & MD \\
\hline THIS WAS GOOD FEEDBACK & 5A & MA & SA & $\mathrm{u}$ & SD & MD \\
\hline $\begin{array}{l}\text { TILL HAVE NO BEARING } \\
\text { ON KY FUTURE BEHAVIOR }\end{array}$ & SA & MA & SA & $\mathbf{u}$ & SD & MD \\
\hline
\end{tabular}


ASSURE THAT THE POLLOWING PIECE OF FEEDBACR IS GIVEN TO YOU BY MARy

TOU RRAIIT BCRFAED OP BY LOSIFG TIAT RBPORT. YOUR DRSK IS SUCA A KRSS YOU CAN NBVER TIND AKYTHITG. TOO SHOULD BE MORP CARRFUI, ABOUT WRERB YOU PUT THIKGS, LSPBCIAILY IF YOU'RB GOING TO KBBP YOUR DESK LTKB TBATI

PLERSB RRSPOND TO THE POLIONTHG BTATRMRATS AS YOU WOULD IT cisy

FAD SAID THQ ABOVR TO YO0:

\begin{tabular}{|c|c|c|c|c|c|c|}
\hline $\begin{array}{ll}\mathbf{S} & \mathbf{A} \\
\mathbf{T} & \mathbf{G} \\
\mathbf{R} & \mathrm{R} \\
\mathbf{O} & \mathbf{E} \\
\text { N } & \text { E } \\
\mathbf{G} & \\
\mathbf{I} & \\
\mathbf{Y} & \end{array}$ & $\begin{array}{ll}\text { K } & \mathbf{A} \\
\mathbf{O} & \mathbf{G} \\
\mathrm{D} & \mathbf{R} \\
\mathbf{B} & \mathbf{E} \\
\mathrm{R} & \mathbf{E} \\
\mathbf{A} & \\
\mathbf{T} & \\
\mathbf{E} & \\
\mathbf{L} & \\
\mathbf{Y} & \end{array}$ & $\begin{array}{ll}\mathbf{S} & \mathbf{A} \\
\mathbf{L} & \mathbf{G} \\
\mathbf{I} & \mathbf{R} \\
\mathbf{G} & \mathbf{E} \\
\mathbf{H} & \mathbf{E} \\
\mathbf{T} & \\
\mathbf{L} & \\
\mathbf{Y} & \end{array}$ & $\begin{array}{l}U \\
\text { H } \\
\text { D } \\
\text { E } \\
\text { C } \\
I \\
D \\
\text { E } \\
\text { D }\end{array}$ & $\begin{array}{ll}S & D \\
L & I \\
I & S \\
G & A \\
H & G \\
T & R \\
L & E \\
X & E\end{array}$ & $\begin{array}{l}\mathrm{H} \\
\mathbf{O} \\
\mathrm{D} \\
\mathrm{E} \\
\mathrm{R} \\
\mathrm{A} \\
\mathrm{T} \\
\mathrm{E} \\
\mathrm{I} \\
\mathrm{Y}\end{array}$ & $\begin{array}{l}\text { D } \\
\text { I } \\
\mathbf{S} \\
\mathbf{A} \\
\mathbf{G} \\
\mathbf{R} \\
\mathbf{E} \\
\mathbf{E}\end{array}$ \\
\hline
\end{tabular}

\begin{tabular}{|c|c|c|c|c|c|c|}
\hline $\begin{array}{l}\text { I POUND THIS FEEDBACK TO } \\
\text { BE HELPFUL }\end{array}$ & $\mathbf{s} \boldsymbol{A}$ & $\mathbf{K A}$ & $\mathbf{s} \lambda$ & $\mathbf{U}$ & SD & KD \\
\hline $\begin{array}{l}\text { I'R GLAD THIS PERSON } \\
\text { BROUGET THIS TO KY ATTENTION }\end{array}$ & $\mathbf{S A}$ & $\mathbf{M \lambda}$ & SA & $\mathbf{U}$ & SD & MD \\
\hline $\begin{array}{l}\text { THIS FEEDBACK HURT HX } \\
\text { FEELTHGS }\end{array}$ & $\mathbf{S A}$ & หม & SA & $\mathbf{U}$ & SD & MD \\
\hline $\begin{array}{l}\text { I HOULD CONTINUE A DIALOGUE } \\
\text { WITH THIS PERSON ON THIS } \\
\text { SUBTECT }\end{array}$ & SA & $\mathbf{K \lambda}$ & SA & $\mathbf{U}$ & SD & MD \\
\hline $\begin{array}{l}\text { THIS PERSON SHOULD NOT HAVE } \\
\text { SAID TRIS TO KE }\end{array}$ & $\mathbf{S A}$ & MA & $\mathbf{s \lambda}$ & $\mathbf{u}$ & SD & HD \\
\hline
\end{tabular}




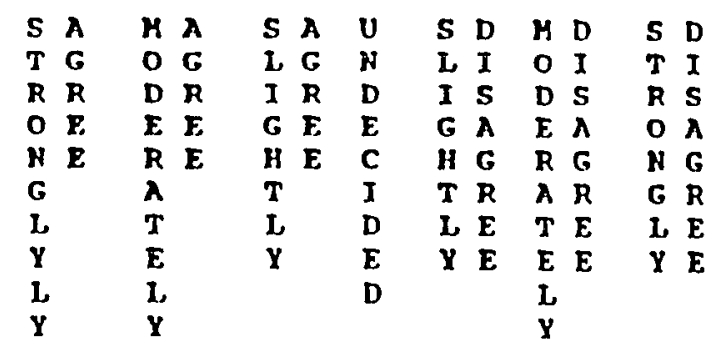

\begin{tabular}{|c|c|c|c|c|c|c|}
\hline LIKE THIS TO TIIEHSELVES & $\mathbf{S A}$ & $\mathbf{M \Lambda}$ & $\mathbf{s} \boldsymbol{x}$ & $\mathbf{U}$ & SD & MD \\
\hline $\begin{array}{l}\text { THIS FEEDBACK COULD HAVE } \\
\text { BEEN PHRASED BETTER }\end{array}$ & $\mathbf{s \lambda}$ & MA & $\mathbf{s} \boldsymbol{\lambda}$ & $\mathbf{U}$ & SD & MD \\
\hline $\begin{array}{l}\text { THIS PIECE OF FEEDBACR } \\
\text { WOULD BE OF USE TO } \mathrm{ME}\end{array}$ & SA & $\mathrm{MA}$ & SA & $\mathbf{U}$ & SD & MD \\
\hline $\begin{array}{l}\text { I WOULD ACT DIFFERENTLY } \\
\text { HAVING RECEIVED THAT PIECE } \\
\text { OF FEEDBACK }\end{array}$ & $\mathbf{s} \boldsymbol{x}$ & MA & $\mathbf{S A}$ & $\mathbf{u}$ & SD & HO \\
\hline $\begin{array}{l}\text { I WAS OFFENDED BY THIS } \\
\text { PIECE OF FEEDBACK }\end{array}$ & $\mathbf{S \Lambda}$ & КA & $\mathbf{S A}$ & $\mathrm{U}$ & SD & MD \\
\hline THIS WAS GOOD FEEDBACK & SA & MA & SA & $\mathbf{u}$ & SD & MD \\
\hline $\begin{array}{l}\text { THL PIECE OF FEEDBACK } \\
\text { WIL WHVE WO BRARING } \\
\text { ON HY FUTURE BEHAVIOR }\end{array}$ & $\mathbf{s \Lambda}$ & hi & $\mathbf{S A}$ & $\mathbf{U}$ & SD & MD \\
\hline
\end{tabular}

